Delft University of Technology

\title{
Shear Experiments of Prestressed Concrete Bridge Girders
}

Lantsoght, E.O.L.; Zarate Garnica, G.I.; Zhang, F.; Park, Min-Kook; Yang, Y.; Sliedrecht, Henk

\section{Publication date}

2021

Document Version

Accepted author manuscript

Published in

ACI Structural Journal

\section{Citation (APA)}

Lantsoght, E. O. L., Zarate Garnica, G. I., Zhang, F., Park, M-K., Yang, Y., \& Sliedrecht, H. (2021). Shear Experiments of Prestressed Concrete Bridge Girders. ACl Structural Journal, 118(3), 117-130.

https://www.concrete.org/publications/internationalconcreteabstractsportal.aspx?m=details\&ID $=51729360$

\section{Important note}

To cite this publication, please use the final published version (if applicable).

Please check the document version above.

\section{Copyright}

Other than for strictly personal use, it is not permitted to download, forward or distribute the text or part of it, without the consent of the author(s) and/or copyright holder(s), unless the work is under an open content license such as Creative Commons.

Takedown policy

Please contact us and provide details if you believe this document breaches copyrights.

We will remove access to the work immediately and investigate your claim. 


\section{GIRDERS}

Eva O. L. Lantsoght ${ }^{1,2}$, Gabriela Zarate ${ }^{1}$, Fengqiao Zhang ${ }^{1}$, Min-kook Park ${ }^{1}$, Yuguang Yang ${ }^{1}$, and

Henk Sliedrecht ${ }^{3}$

${ }^{2}$ Universidad San Francisco de Quito, Quito, Ecuador

${ }^{3}$ Rijkswaterstaat, Ministry of Infrastructure and the Environment, Utrecht, the Netherlands

Biography: ACI member Eva Lantsoght is a full professor at Universidad San Francisco de Quito and an assistant professor at Delft University of Technology. She is a member of ACI 445-0D Shear Databases, ACI-ASCE 421 Design of Reinforced Concrete Slabs, ACI 342 Evaluation of Concrete Bridges and Bridge Elements, vice chair of ACI 445-0E Torsion, and an associate member of ACI 437 Strength Evaluation of Existing Concrete Structures, and ACI-ASCE 445 Shear and Torsion.

Gabriela Zarate is a PhD candidate at Delft University of Technology. She received her BS in civil engineering from the National Autonomous University of Mexico, Mexico City, Mexico in 2014, and her MS in civil engineering from Delft University of Technology, Delft, the Netherlands in 2018. Her research interests include shear behavior of RC members, measuring techniques and assessment of existing structures.

Fengqiao Zhang is a $\mathrm{PhD}$ student at Delft University of Technology, Delft, the Netherlands. She received her MS in civil engineering from Delft University of Technology, Delft, the Netherlands in 2017. Her research topic is wave-based structural assessment of existing concrete bridges using 21 smart aggregates.

Yuguang Yang is an assistant professor at Delft University of Technology, Delft, the Netherlands. He received his BS in civil engineering from Shanghai Jiao Tong University, Shanghai, China in 2005, and his MS and PhD in civil engineering from Delft University of Technology, Delft, the 
1 members, assessment of existing structures and measurement techniques.

2 Min-Kook Park is a Post-Doctoral Researcher at Delft University of Technology, Delft, the

3 Netherlands. He received his $\mathrm{BS}, \mathrm{MS}$ and $\mathrm{PhD}$ in architectural engineering from the University of

4 Seoul. His research interests include the shear behavior of reinforced concrete and prestressed 5 concrete members and the application of precast concrete.

6 Henk Sliedrecht is a senior consultant at Rijkswaterstaat, Ministry of Infrastructure and

7 Watermanagement, Utrecht, The Netherlands. He received his MSc from Delft University of

8 Technology. His research interests include the assessment of existing concrete bridges in particular 9 methods of analysis and standards for structural safety.

\section{ABSTRACT}

12 For the assessment of existing slab-between-girder bridges, the shear capacity and failure mode are 13 under discussion. Previous research showed that the static and fatigue punching capacity of the 14 slabs is sufficient as a result of compressive membrane action. The girders then become the critical elements. This research studies the shear capacity of prestressed concrete bridge girders. For this purpose, four (half) girders were taken from an existing bridge that was scheduled for demolition and replacement and tested to failure in the laboratory. Two loading positions were studied. The 18 results show that there should be a distinction between the mode of inclined cracking and the actual 19 failure mode. In addition, the results show that for prestressed concrete girders the influence of the shear span to depth ratio should be considered for shear span to depth ratios larger than 2.5. These 21 insights can be used for the assessment of existing slab-between-girder bridges in the Netherlands.

23 Keywords: bridge assessment; concrete bridges; flexure-shear; large-scale testing; prestressed concrete; shear; shear-compression; shear-tension 
2 In the Netherlands, approximately 70 (Ensink et al., 2018; Ensink et al., 2019; Koekkoek et al.,

3 2018) existing slab-between-girder bridges require assessment (Lantsoght et al., 2019b). This bridge

4 type consists of post-tensioned concrete girders, with thin, transversely prestressed decks cast in

5 between the top flanges of the girders. In addition, prestressed diaphragm beams are applied in

6 these bridges, typically at the supports and at $1 / 3^{\text {rd }}$ of the span length. These three elements are

7 standard for all the existing slab-between-girder bridges in the Netherlands. Initial assessment

8 indicated that the thin decks are the part of the structure with the highest Unity Check (ratio of

9 factored load effect to factored capacity, used in the Netherlands instead of a Rating Factor).

10 Experimental research (Amir, 2014; Amir et al., 2016) showed that the capacity of the decks is 2.32

11 times the capacity as predicted with the punching provisions of NEN-EN 1992-1-1:2005 (CEN,

12 2005) as a result of compressive membrane action. Additional experiments (Lantsoght et al., 2019c;

13 d) showed that under fatigue loading, compressive membrane action also acts, and that it is 14 therefore allowed to include the insights of these series of experiments to the assessment of slab15 between-girder bridges in the Netherlands. With these research insights, the thin transversally 16 prestressed decks are no longer the members with the highest Unity Check in the bridge structure. 17 Now, the bulb-T girders in the longitudinal direction become the critical members. Upon 18 assessment, these girders are found to be particularly critical for a shear-tension failure (Roosen et 19 al., 2019a; b). For assessment, shear-tension and flexure-shear are both verified. Shear-tension 20 (Arthur, 1965; Mahgoub, 1975; Roosen, 2018; Vergeer, 2019) failures (also referred to as web21 shear failures) occur in the region of the girder that is not cracked in bending, and are characterized 22 by a diagonal crack in the thin web of the girder, perpendicular to the direction of principal tension. 23 On the other hand, flexure-shear (Collins et al., 2016; Hicks, 1958; Laskar et al., 2010) failures 24 occur in the region of the girder that is cracked in bending. The flexure-shear crack originates from 25 a flexural crack in the bottom flange, which then deviates in the web, resulting in a diagonal crack. 
An additional cause for concern with the post-tensioned bulb-T girders is that non-code-

2 compliant (with respect to the current codes) stirrups are used. The stirrups in these girders follow

3 the shape of the cross-section, which could lead to spalling off of the concrete cover when large stresses develop in the stirrups. Moreover, the amount of stirrups in these girders is often be low the minimum shear reinforcement limit prescribed by the currently governing Eurocode 2 NEN-EN 1992-1-1:2005 (CEN, 2005).

The Helperzoom bridge, see Figure 1 ((Jayananda, 2018)), a slab-between-girder bridge from 1965, is demolished as a result of the development of the new perimeter around the city of Groningen. Therefore, it was possible to take girders from the bridge to test in the laboratory. When assessed according to the Dutch codes for the assessment NEN 8700:2011 (Code Committee 11 351001, 2011a), with loads from NEN 8701:2011 (Code Committee 351001, 2011b) and further 12 stipulations for highway bridges in the RBK RTD 1006:2013 (Richtlijnen beoordeling kunstwerken 13 - guidelines assessment bridges) (Rijkswaterstaat, 2013), the outc ome for the Unity Check for shear is 1.69 for the edge girders and 1.05 for the interior girders. The edge girder is found to have the largest Unity Check in the shear-tension region, whereas the interior girder has the largest Unity Check in the flexure-shear region (Movares, 2013). As such, the girders are representative of the girders in slab-between-girder bridges for which there are concerns regarding the shear capacity. To

18 facilitate testing in the laboratory, the girders were cut in half, and the halves of four girders were transported to the laboratory and tested.

The goal of the experiments was twofold: 1) determine the governing shear failure 21 mechanism of typical bridge girders as used in the Dutch slab-between-girder bridges, and 2) 22 facilitate the comparison with nonlinear finite element models, which may be used for the 23 assessment of slab-between-girder bridges. This paper will address the first goal of the experiments 24 and give insight on the effect of the shear span to depth ratio on the shear capacity. While the focus in this work is on the girders taken from the Helperzoom bridge, the findings with regard to the 
1 shear capacity and governing shear failure mode are relevant for all thin-webbed prestressed

2 elements, such as the post-tensioned bulb-T girders, prestressed inverted T-girders in slab-on-girder

3 bridges, and box girders with thin webs (Roosen et al., 2018). As such, this work is relevant for

4 about $25 \%$ of all 6000 bridges in the Dutch highway network.

The focus of this article is on the experimental results and failure modes. A companion paper (Park et al., in review) discusses the comparison to the capacity predicted with current code provisions and a second companion paper compares the outcomes with nonlinear finite element models (Mustafa et al., in review).

\section{RESEARCH SIGNIFICANCE}

This series of experiments uses specimens recovered from a bridge scheduled for demolition and

11 replacement. As such, the specimens contain details such as the non-code-compliant stirrups, 12 geometry, cross-section, and prestressing profile that are typically omitted or simplified in 13 laboratory testing. The experiments give a unique insight in the capacity and failure mode of 14 prestressed concrete girders. In particular, the experiments found that the governing shear cracking mode is flexure-shear, contrary to the shear-tension mode expected from the assessment. The noncode-compliant stirrups were shown to be able to carry shear. These insights can improve the shear assessment of slab-between-girder bridges.

\section{LITERATURE REVIEW}

19 Most experiments in the literature that deal with the shear capacity of prestressed beams, are carried 20 out on specimens that are suitable for the laboratory in terms of size and in terms of detailing. In 21 this paragraph, results of large beams tested in the lab are summarized and the failure mode is analyzed. (Labib et al. 2014) tested large prestressed bulb-T girders with a span length of $7.62 \mathrm{~m}=$

$2325 \mathrm{ft}$, and observed shear-tens ion and flexure-shear cracking in the girders. In specimens with low 24 amounts of transverse reinforcement, failure occurred right at formation of the shear crack. In other 25 specimens, failure occurred after formation of the shear crack by crushing of the concrete 
1 compressive struts. (Kuchma et al., 2008) tested 10 girders in the laboratory at both ends. The final

2 failure modes in the girders were shear-compression failure, diagonal field crushing, and, in a few 3 cases, stirrup rupture, horizontal slip, and local crushing. (Oh and Kim, 2004) made similar observations on the behavior of $10.8 \mathrm{~m}(35.4 \mathrm{ft})$ long girders tested in the laboratory. (Shahawy and Batchelor, 1996) observed flexure-shear failures in their full-scale girder tests. Other authors who observed shear-compression failures or crushing failure of the diagonal compression field are (Mahgoub, 1975). These observations are in line with an analysis of the (Dunkelberg et al., 2018) database of shear tests on prestressed beams: for beams with stirrups, the governing failure mode is only for a few experiments shear-tension, as the activation of stirrups after shear cracking results in a different final failure mode. (Kar, 1969) explains this observation based on the high stresses in the concrete compression zone after formation of a diagonal crack.

In experiments, the effect of the shape of the cross-section is observed: members with thick flanges have a higher shear capacity than thin-webbed members, which in turn have a higher shear capacity than members with a rectangular cross-section (Collins et al., 2016). (Schramm and Fischer, 2019) and (Herbrand et al., 2017) also observed that members with a flange in compression larger shear spans than in reinforced concrete. (Herbrand and Classen, 2015) identified direct compression arching action as the most important shear-carrying mechanis $m$ in their experiments. (De Wilder et al., 2018) observed this for beams with an I-shaped cross-section and shear span to 21 depth ratios between 2.91 and 3.19. (Herbrand and Classen, 2015) noticed the contribution of arching action for girders with internally bonded tendons and additional external prestressing with a 23 shear span to depth ratio of 3.6. Similarly, (Shen et al., 2015) reported arching action for a shear span to depth ratio of 4 . The seminal work by (Hicks, 1958) identified the region of diagonal compression failures to govern for shear spans up to $4.5-5$. 
A recent series of experiments (Schramm and Fischer, 2019) foc used on the shear capacity

2 of girders with old stirrup types, such as open stirrups and two-part stirrups and showed that the old

3 stirrup types work properly for shear. The authors, however, did not look at stirrups that follow the shape of the cross-section. Another important consideration for existing girders is the detailing at the end of the girders in the anchorage zone. (Ross et al., 2015) found that the end region detailing, and especially the placement of fully bonded strands, had a significant influence on the specimen behavior and capacity.

Only a few series of experiments have been carried out on beams taken from existing bridges. The first series of experiments used girders from a decommissioned bridge in Orem, Utah. (Higgs et al., 2015) tested girders taken from a bridge that had been in service for seven years. The

11 flexural cracking strength was used to estimate the level of prestressing in the girders, and 12 subsequently three girders were tested in shear for different $a / d$ distances, with $a$ the shear span and $13 d$ the effective depth. The conclusion of the shear tests was that the AASHTO LRFD (AASHTO, 2018) shear provisions are conservative (all within $12 \%$ conservative) for the studied girders. Similarly, (Osborn et al., 2012; Osborn, 2010) tested eight AASHTO Type 2 girders: six taken from the decommissioned I-215 bridge near Salt Lake City, Utah with steel corrosion, and two longer 17 girders from a highway bridge in southern Utah. Both bridges had been in service for 40 years. Six 18 girders were used to determine the prestressing level, and two girders were tested in shear close to 19 the support. It was found that the AASHTO code is overly conservative for loads close to the 20 support, and that strut-and-tie methods are more suitable for such cases. (Zwicky and Vogel, 2000; 21 Zwicky, 2002) tested five girders with a low stirrup ratio from the Wassnerwald viaduct, which had been in service for 30 years and had corrosion ingress. The failure modes observed were flexure in 23 four experiments (two of which were analytically expected to fail in shear) and a failure by crushing 24 of the compression strut in one test. (Vill et al., 2011) tested continuous girders with insufficient shear reinforcement according to the current codes from a bridge built in 1952 in Austria. (Martin et 
1 al., 2011) tested a 40-year old bridge girder from Tulsa, OK to check the shear performance of

2 girders designed for shear with the old quarter-point rule, which is less conservative than the current

3 AASHTO provisions. The outcome of the tests was that the girders exceeded the nominal strengths of former and current AASHTO provisions, as well as of the ACI 318 (ACI Committee 318, 2008) code requirements.

\section{EXPERIMENTAL INVESTIGATION}

\section{$7 \quad$ Geometry of girders}

8 The bulb-tee girders are interior girders, taken from the viaduct Helperzoom, a slab-between-girder

9 bridge. Figure 2 shows the cross-section of the girder. The cross-sectional area is $A_{g}=507 \times 10^{3}$ $10 \mathrm{~mm}^{2}\left(811.2 \mathrm{in}^{2}\right)$, and the moment of inertia is $I_{g}=7.47 \times 10^{10} \mathrm{~mm}^{4}\left(1.795 \times 10^{5} \mathrm{in}^{4}\right)$. The neutral 11 axis of the cross-section is at $492 \mathrm{~mm}(19.4 \mathrm{in}$.) from the top of the girder. The girders are $23.4 \mathrm{~m}(76.8 \mathrm{ft})$ long and their span length is $23 \mathrm{~m}(75.5 \mathrm{ft})$. For handling 13 and testing of the girders, they are sawn in half. Due to variability of the sawing action in the field, 14 the resulting dimensions of the four girders differ from each other, see Table 1. Figure 3 shows the side view of a girder, including the tendon layout, and position of hammerhead, tapering part, and cross-beam. Detailed information can be found in the preparation report (Lants oght et al., 2019a) of the experiments, as well as in the measurement report (Lantsoght et al., 2019e).

\section{Material properties}

19 The concrete properties are determined based on twelve core samples taken from the viaduct Helperzoom (Linthorst and Teunissen, 2009). The average cube concrete compressive strength is

$21 f_{c m, \text { cube }}=76.3 \mathrm{MPa}(11,070 \mathrm{psi})$, with a characteristic cube concrete compressive strength of $f_{c k, c u b e}=$ 62.7 MPa (9094 psi), which corresponds with concrete class C55/67 from NEN-EN 1992-1-1:2005

23 (CEN, 2005). The average splitting tensile strength is $f_{c t m}=5.4 \mathrm{MPa}(783 \mathrm{psi})$, and the characteristic 24 splitting tensile strength is $f_{c t k}=4.0 \mathrm{MPa}$ (580 psi). Additional core testing was used to determine the elastic modulus of the concrete in the girders as 39,548 $\mathrm{MPa}(5734 \mathrm{ksi})$. 
The prestressing tendons are made of the so-called "40-ton cables" as used in the 1960s.

2 Nine samples of prestressing steel are used to determine its stress-strain diagram, see Figure 4. The

3 average ultimate strength of the prestressing steel is $f_{\text {pum }}=1824 \mathrm{MPa}(264.5 \mathrm{ksi})$ with an ultimate

4 strain of $\varepsilon_{p u}=0.0535$. The average stress that corresponds to a strain of 0.01 is $f_{p 0.1 m} 1433 \mathrm{MPa}$ $5 \quad(207.8 \mathrm{ksi})$. (four samples from the stirrups and five samples from the longitudinal reinforcement) are used to determine the properties of the reinforcement steel. The average yield strength is $f_{y m}=454 \mathrm{MPa}$ $(65,850 \mathrm{psi})$ and the average tensile strength is $f_{u m}=655 \mathrm{MPa}(95,000 \mathrm{psi})$.

\section{Reinforcement}

11 The prestressing consists of ten tendons each with twelve strands of $7 \mathrm{~mm}$ (0.28 in.) diameter, see

12 Figure 5. The resulting area of each prestressing tendon is $A_{p, 1}=462 \mathrm{~mm}^{2}\left(0.7 \mathrm{in}^{2}\right)$. As can be seen 13 in Figure 3, tendon numbers 4 through 10 are anchored at the hammerhead. The position of tendons 149 and 10 coincide with regard to their vertical position, and the same holds true for tendons 7 and 8 . Tendons 1, 2 and 3 are anchored at the top of the cross-section, as indicated in Figure 3. All tendon 16 profiles are draped.

Over the height of the cross-section (see Figure 2), $16 \phi 10 \mathrm{~mm}(0.4$ in $\approx \# 3$ bars $)$

18 longitudinal bars are provided. This layout results in an area of tension steel of $A_{s}=628 \mathrm{~mm}^{2}(0.97$ $\left.19 \mathrm{in}^{2}\right)$ and an area of compression steel of $A_{s}{ }^{\prime}=628 \mathrm{~mm}^{2}\left(0.97 \mathrm{in}^{2}\right)$.

The provided stirrups are $\phi 10 \mathrm{~mm}(0.4 \mathrm{in} \approx \# 3$ bars $)$ with a spacing of $400 \mathrm{~mm}(15.7 \mathrm{in})$.

21 The shape of the stirrups follows the shape of the cross-section, see Figure 2, which is not allowed according to current codes (such as NEN-EN 1992-1-1:2005 (CEN, 2005)), since there is a risk of

23 spalling off of the concrete cover due to tension stresses provoked by the shape of the stirrup 24 (Roosen et al, 2019a). The amount of stirrups is determined as: 


$$
\rho_{w}=\frac{A_{s w}}{s b_{w} \sin (\alpha)}
$$

2 with $A_{s w}$ the area of a stirrup, $s$ the stirrup spacing, $b_{w}$ the web width, and $\alpha$ the angle between the

3 shear reinforcement and the longitudinal axis (between $45^{\circ}$ and $90^{\circ}$ ). For the Helperzoom girders,

$4 \rho_{w}=0.196 \%$, which is below the Eurocode 2 (NEN-EN 1992-1-1:2005 (CEN, 2005)) minimum

5 amount of stirrups of $\rho_{w, \min }=0.215 \%$.

\section{$6 \quad$ Test setup}

7 Figure 6 gives an overview of the test setup. The span length selected for testing the girders is $l_{\text {span }}=$ $9.6 \mathrm{~m}(31.5 \mathrm{ft})$. The load is applied through a loading plate of $300 \mathrm{~mm} \times 300 \mathrm{~mm}(11.8 \mathrm{in} \times 11.8$ in). The beam is supported on loading plates of $100 \mathrm{~mm} \times 560 \mathrm{~mm}(3.9 \mathrm{in} \times 22.0 \mathrm{in})$, see Figure 7 .

To avoid slipping of the prestressing steel and development of a splitting failure on the side

11 with the saw cut, external transverse prestressing bars are used (see Figure 8). The amount of external transverse prestressing applied varies per experiment.

The load is applied by means of a hydraulic jack, built into a frame that is anchored to the strong floor of the laboratory, see Figure 6. To study crack opening and development, a loading protocol with different load steps of loading and unloading is used, see for example Figure 9. In

16 Figure 9, three lower load levels with three cycles per load level are shown: before cracking, after 17 flexural cracking, and after shear-flexure cracking. The fourth load level is an incremental loading to failure. The loading speed is $0.02 \mathrm{~mm} / \mathrm{s}(0.0008 \mathrm{in} / \mathrm{s})$ in all cases, except during the first cycles of HPZ01, when a loading speed of $0.01 \mathrm{~mm} / \mathrm{s}(0.0004 \mathrm{in} / \mathrm{s})$ was used.

\section{Instrume ntation}

21 For each of the four experiments, a slightly different sensor plan was developed. In all experiments, linear variable differential transformers (LVDTs) were used in a grid between the load and the support on the south face of the test specimens, measuring deformations in the vertical and horizontal direction. In addition, two diagonal LVDTs were applied in this grid for experiments 
1 HPZ02, HPZ03, and HPZ04 (with HPZ as abbreviation for Helperzoom). In all experiments, one

2 LVDT is used at the support to measure the support deflections. Under the load, two laser distance

3 finders are used to measure the deflections on the north and south sides of the beams.

A photo camera is used for taking photographs, which are analyzed with digital image correlation (DIC). The DIC setup consisted of a high resolution camera of 8688 by 5792 pixels (Canon EOS 5DS) with a wide angle lens (Sigma $20 \mathrm{~mm}=0.8 \mathrm{in}$ ) and two LED lights. In experiments on HPZ3 and HPZ4, additional cameras with a lens of $49 \mathrm{~mm}$ (1.9 in) and macrolens of $90 \mathrm{~mm}$ (3.5 in) were used to capture the opening of the critical shear crack in the web. To use DIC, we first painted the beam white, and then used a paint roller with black paint to develop a random speckle pattern on the beam. The north face of the test specimens is monitored with 11 cameras. In all experiments, acoustic emissions (AE) sensors are used to follow (micro) crack 13 development and propagation. The AE sensors had a central frequency of $60 \mathrm{kHz}$, narrow banded. The AE signals that arrived at the sensors with a peak amplitude over $40 \mathrm{~dB}$ were recorded. In experiments HPZ02, HPZ03, and HPZ04, smart aggre gates are cast into the beam in holes that were drilled for the purpose. Smart aggregates consist of a piezo-electric layer between two marble layers. The piezo electric layer allows the sensors to act as both actuators of ultrasonic waves and receivers. As they also have similar mechanical properties to normal aggre gates, they are referred to as Smart Aggregates (SAs). After placing the smart aggregate, the drilled hole was repaired with a high strength mortar. can be found in the measurement report of the experiment (Lantsoght et al., 2019e), and further analysis of the DIC and AE can be found in (Zhang et al., in review). Figure 10 shows the sensor plan used for HPZ04. 
2 Description of expe riments

$3 \quad H P Z 01$

4 Before the beginning of HPZ01, the application of the vertical prestressing at the saw cut led to 5 cracks in the flanges. For the first loading cycles to $500 \mathrm{kN}$ (112.5 kip), the loading speed was 0.01

$6 \mathrm{~mm} / \mathrm{s}(0.0004 \mathrm{in} / \mathrm{s})$, afterwards the loading speed was increased to $0.02 \mathrm{~mm} / \mathrm{s}(0.0008 \mathrm{in} / \mathrm{s})$. The

7 first flexural crack developed at $965 \mathrm{kN}$ (217 kip). The first shear crack (a flexure-shear crack) 8 developed at $1344 \mathrm{kN}$ (302 kip). Figure 11 shows the development of the cracks during the 9 experiment. The ultimate load was $1893 \mathrm{kN}$ (426 kip), at which a shear-compression failure took 10 place.

11 HPZ02

12 HPZ02 is a repeat test of HPZ01, but now the loading speed is constant at $0.02 \mathrm{~mm} / \mathrm{s}(0.0008 \mathrm{in} / \mathrm{s})$.

13 The vertical prestressing bars at the saw cut were applied at with a larger spacing in between and no cracking developed in the flange. The first flexural crack developed at $1001 \mathrm{kN}$ (225 kip). The first two shear cracks, both flexure-shear cracks, developed at $1299 \mathrm{kN}$ (292 kip). Shear-compression failure occurred at $1849 \mathrm{kN}$ (416 kip). In general, the behavior of the girder during this experiment was very similar to the behavior of HPZ01, see Figure 12 for selected DIC-processed photographs

18 of the cracking pattern. After failure, the anchorage end of the prestressing tendon anchored in the 19 flange was visible next to the loading plate.

HPZ03

21 In HPZ03, the load was placed farther from the support, at $4.4 \mathrm{~m}=14.5 \mathrm{ft}$. In this experiment, three cameras were used: one to capture the global distribution of strains using a $20 \mathrm{~mm}(0.8 \mathrm{in}$.) wideangle lens, one to capture the opening of the critical shear crack in the web, and one to capture the opening of the shear-tension crack closer to the support. The load was applied using cycles and the duration of the experiment was two days. The first flexural crack developed at $1050 \mathrm{kN}=236 \mathrm{kip}$. 
1 The first shear crack, a flexure-shear crack, developed at $1250 \mathrm{kN}=281 \mathrm{kip}$ between the load and

2 the saw cut. At $1650 \mathrm{kN}=371 \mathrm{kip}$, a shear-tension crack developed between the load and the saw

3 cut. The shear cracks developed up into the top flange. Failure occurred at $1990 \mathrm{kN}=448$ kip by

4 crushing of the concrete in the flange. Figure 13 gives an overview of the development of cracks

5 during the experiment.

$6 \quad$ HPZ04

7 HPZ04 is a repeat test of HPZ03 (including three cameras for DIC), but a different jack was used:

8 instead of the $2000 \mathrm{kN}$ (450 kip) jack, the 10,000 kN (2250 kip) jack was used, as HPZ03 had a

9 failure load close to the maximum capacity of the jack used in that experiment. The first flexural

10 crack developed at $1100 \mathrm{kN}=248 \mathrm{kip}$. The first inclined crack, a flexure-shear crack, developed at

$111450 \mathrm{kN}=326 \mathrm{kip}$. The shear cracks reached the compress ion flange at $2050 \mathrm{kN}=461 \mathrm{kip}$. Figure

1214 gives an overview of the development of cracks during the experiment. Failure occurred at 2380

$13 \mathrm{kN}=536 \mathrm{kip}$ by crushing of the concrete in the compression field in the web of the girder.

\section{$14 \quad$ Level of prestre ssing}

15 In the first calculations, the prestressing stress was estimated according to the Dutch Guidelines for 16 the Assessment of Bridges (RBK (Rijkswaterstaat, 2013)). The assumed working prestressing le vel 17 is $0.52 f_{p k}=868 \mathrm{MPa}(125,860 \mathrm{psi})$. Since the girders were cut in half before transportation to the lab 18 and testing, further losses may have occurred. Visual inspection of the saw cut revealed no 19 significant retraction of the prestressing tendons. To quantify the prestressing stress level, we used 20 three methods:

21 1) Determination based on the cracking moment observed in the experiment and the ACI 31819 (ACI Committee 318, 2019) expression for the cracking moment, first determined based on the overall load-displacement diagram and then refined with the results from the LVDT measurements.

2) Direct experimental determination through core drilling and through cutting of the tendons 
3) More advanced sectional analys is with a layered model, validated with Response-2000 (Bentz, 2010)

Table 2 shows an overview of the results of the prestressing stress according to the different methods. The LVDT results are more accurate than the test results from the load-deflection diagram. In the load-deflection diagram, the change in stiffness due to cracking may be difficult to observe, and may be a gradual change, whereas in the LVDT results the de velopment of a crack, when the crack is in the region monitored by the LVDT, results in a clear increase in the measurement results. For the direct measurement results, we observed that the core drilling method

11 gave widely differing results, and that also the method of cutting through the tendons directly 12 resulted in variability among the specimens and among the tests on the same specimen. Finally, the 13 sectional analysis results evaluate the cross-section with a layered model, which makes it more 14 precise than the first method, based on the cracking moment expression of ACI 318-19. This layered analys is model considered the compressive and tensile stress-strain re lationships of concrete by Collins et al. (Collins, 1991; Vecchio, 1986), and the tensile stress-strain relationships of mild 17 and prestressing steel using the elasto-perfectly plastic model (Scholz, 1990) and the modified 18 Ramberg-Osgood model (Mattock, 1979), respectively. Once the extreme top and bottom fiber of 19 the cross-section are assumed, the tensile and compressive forces of each layer are calculated 20 according to the strain compatibility and force equilibrium conditions, and the moment-curvature 21 relationship is derived as a result. This result is compared with the moment-curvature calculated through the strain of two layers measured in the web of the section where the load was applied in 23 the experiment to determine the correct working prestressing level. In addition, the method is 24 validated with Response-2000, showing good correspondence, and thus we will use the prestressing 25 stress from the layered sectional analysis method in the next analyses. 
Test results and failure modes

2 Table 3 gives an overview of the experimental results and Figure 15 gives the envelopes of the

3 load-displacement diagrams of the four experiments. The failure mode is reported based on the

4 mode of shear cracking (before failure occurred) and then the ultimate failure mode. For all

5 experiments, the first shear crack to develop was a flexure-shear (FS) crack. The final failure mode

6 was a function of the position of the load. For the experiments with the loads closer to the support,

7 the failure mode was shear-compression (SC) as a strut could develop between the load and the

8 support. For HPZ03, the failure was initiated by crushing of the concrete under the loading plate,

9 indicated by CC. For HPZ04, failure occurred by crushing of the concrete in the compression field

10 after formation of a truss-like pattern of shear cracks indicated by CF. The acoustic emission

11 sensors can detect micro cracking about $50 \mathrm{kN}$ (11 kip) before the DIC or the bare eye can notice

12 cracking. The detailed disc ussion of the AE measurements is given in the analysis report (Lantsoght

13 et al., 2020).

Subsequently, in

15 Table 4 are the results of the experiments in terms of sectional shear. The sectional shear in 16 the experiment is the result of the self-weight, the prestressing, and externally applied load. 17 The sectional shear at the ultimate $V_{u}$ and at shear cracking $V_{s c r}$ are given for two positions: 18 under the load, and for the position measured after the experiment where the critical shear crack crosses the midheight of the web. This table also gives insight in the further increase in capacity after shear cracking through the value $V_{\text {add }}$. We can see in

21 Table 4 that this value can partially be explained by the activated stirrups crossing the critical 22 shear crack, $V_{\text {stirrup }}$ and the shear-reinforcing action of the prestressing tendon. This shear23 reinforcing action is calculated by evaluating which tendons cross the she ar crack and under which angle, and then calculating the vertical component of the force which results from the increase in stress during the experiment. We can see that for the first expe riments, because of 
1 the tendon layout, this possible shear-reinforcing contribution is small. However, for the next

two expe riments, the contribution is larger because one of the tendons enters from its point of anchorage in the top flange. Since this value, as well as $V_{\text {stirrup }}$ is calculated based on the measured position of the critical she ar crack, the results are taken as the same for both

\section{studie d $x$-positions in}

Table 4.

\section{Influence of loading position}

For the HPZ experiments, the influence of the loading position was studied by testing the specimens at two different positions. The reader should keep in mind the tendon layout, which implies different amounts of prestressing in the cross-sections close to the support versus further from the support. As a result, the cracking moment is larger for HPZ03 and HPZ04 than for HPZ01 and HPZ02. To study the influence of the loading position, we should compare the results at inclined cracking. Since in all experiments the first inclined crack to develop was a flexure-shear crack, we will compare the values for the sectional shear at the inclined cracking load. On the other hand, comparing the sectional shear at failure does not allow for a one-on-one comparison, as different failure modes occurred in the experiments.

\section{Analyzing the results from}

Table 4 shows that for $a / d_{E C}=3.6$ the average value of $V_{s c r}=781 \mathrm{kN}(176 \mathrm{kip})$ and that for $a / d_{E C}=$ 4.9 the average value of $V_{s c r}=438 \mathrm{kN}$ (98 kip) at the position of the critical shear crack. For a $36 \%$ decrease in shear span to depth ratio, the sectional shear at inclined cracking increases by $78 \%$. The value of $V_{s c r}$ is determined based on the contributions of the selfweight, prestressing, and externally applied load. If we consider the effect of prestressing on the capacity side instead of on the loading side, we can compare the value of $V_{s c r}-V_{p}$. The average value of $V_{s c r}-V_{p}$ for $a / d_{E C}=3.6$ equals $961 \mathrm{kN}$ (216 kip) and for $a / d_{E C}=4.9$ the average value equals $730 \mathrm{kN}$ (164 kip). In other words, for $V_{s c r}-V_{p}$ the sectional shear at inclined cracking increases by $32 \%$ for a decrease in $a / d_{E C}$ of $36 \%$. 
The analysis of the results in the previous paragraphs brings two lessons. The first lesson

2 learned is that, for studying the influence of the loading position, clearer results are obtained when

3 considering the effect of prestressing separately. While Eurocode 2 NEN-EN 1992-1-1:2005 (CEN,

4 2005) includes prestressing on the loading side, and includes the effect of prestressing on the

5 capacity equation, ACI 318-19 (ACI Committee 318, 2019) includes prestressing on the capacity

6 side only. For the Helperzoom experiments the effect of prestressing on the cross-section is a

7 function of the position as a result of the draped tendons. As such, the results are clearer to interpret

8 when the effect of prestressing is removed from the loading side. Based on this approach, the

9 second lesson learned is that a linear dependence between the sectional shear at inclined cracking

10 and the shear span to depth ratio can be observed for values of $a / d_{E C}$ beyond 2.5. While the

11 literature review noted indeed the effect of the shear span to depth ratio for values up to 4 , these

12 outcomes were based on the failure load and/or sectional shear at failure, and the associated failure

13 mode was a shear-compression failure. Here, we observed the effect up to a shear span to depth

14 ratio of almost 5 for the sectional shear at the inclined cracking load. While the number of

15 experiments is limited, this observation suggests a dependence of the sectional shear at the inclined

16 cracking load on the shear span to depth ratio for prestressed concrete bridge girders with draped

17 tendons.

\section{DISCUSSION}

19 In terms of the ultimate shear capacity, the current experiments do not indicate that shear20 compression failures can take place for shear span to depth ratios up to 5, but they can take place up

21 to 3.6. To take into account the shear-compression capacity of existing prestressed concrete bridge 22 girders, further research is necessary. At the moment, it is not possible to include this mechanism 23 for the ultimate capacity in an assessment calculation. Further research is necessary into the 24 required conditions for the development of a direct strut between the load and the support, and for 25 this strut to remain stable and able to carry loading. 
An important conclusion from this study is that a distinction should be made between the mode of inclined cracking (flexure-shear or shear-tension) and the ultimate failure mode (either a

3 shear failure of the critical shear crack, shear-compression failure, or crushing of the concrete compression field). Therefore, for the assessment of existing girder bridges, the analysis should address shear cracking under serviceability limit state conditions, as well as shear failure under ultimate limit state conditions. To make the step from the current experimental work to the assessment of typical slab-between-girder bridges in the Netherlands, further research on the additional load-carrying mechanisms in these types of structures is necessary, including compressive membrane action (Amir et al., 2016) and additional capacity from restraint of deformation resulting from the diaphragm beams (Ensink et al., 2018; Ensink et al., 2019).

Another observation is that the non-code-compliant stirrups were able to carry load. This conclusion follows from the fact that after the development of a shear crack, the load could be

13 further increased, meaning that the stirrups and the direct strut between the load and the support were activated. For HPZ04, a clear truss-like system was observed, indicating the activation of the stirrups. With the exception of one stirrup in HPZ01, no stirrup rupture or shape change was observed. As such, the experiments show that spalling of the cover around the stirrups is not a failure mode that is expected to occur in these types of bridge girders.

\section{SUMMARY AND CONCLUSIONS}

19 In the Netherlands, existing slab-between-girder bridges require assessment. These bridges consist of post-tensioned bulb-T girders, transversally prestressed slabs cast between the top flanges of the

21 girders, and prestressed diaphragm beams. The outcome of previous research on the capacity of the thin cast-in-between slabs was that thanks to the compressive membrane action, the slabs are not the

23 critical elements in these structures. Subsequent analyses then identified the bulb-T girders as the critical elements for the failure mode of shear-tension.

A literature review on the topic led to the following insights: 
- Shear-tension failures are uncommon in experiments, as the activation of stirrups leads to a different failure mode.

- T-shaped beams tend to have a larger shear capacity than rectangular shapes.

- Shear-compression failures are predicted and observed for shear span to depth ratios up to 5.

- Older types of stirrups are able to function properly.

To study the shear capacity of typical girders used in slab-between-girder bridges, four half girders were taken from the Helperzoom bridge, which was scheduled for demolition. These girders have all the detailing found in existing bridges, including non-code-compliant stirrups, a tapering part and hammerhead, and draped tendons. The girders are $1.11 \mathrm{~m}(3.64 \mathrm{ft})$ high and have a length 10 (after sawing the girder in half) between $10.51 \mathrm{~m}$ and $12.98 \mathrm{~m}(34.5 \mathrm{ft}-42.6 \mathrm{ft})$. Testing of the 11 girders was accompanied by testing of the following material properties: concrete compressive strength, concrete tensile strength, modulus of elasticity of the concrete, stress-strain behavior of the prestressing steel and mild steel, and stress in the prestressing tendons in the girders. From these experiments, we can draw the following conclusions:

- To determine the working prestressing level in the girders, the most consistent results were obtained by using a layered sectional analys is model. This analysis revealed that the working prestressing level was between $80-90 \%$ of the level recommended by the Dutch Guidelines for the Assessment of Bridges (Rijkswaterstaat, 2013).

- The critical mode of inclined cracking observed in the experiments is flexure-shear cracking. Shear-tension cracking occurred later during the test. Shear-tension failures did not occur, contrarily to the expectations from the assessment of the slab-between-girder bridges.

- The non-code-compliant stirrups were activated after inclined cracking and could carry load. The stirrups in the Helperzoom girders have a stirrup reinforcement ratio of $0.196 \%$ which is slightly lower than the minimum amount of stirrups prescribed by Eurocode 2 NEN-EN 
1992-1-1:2005 of 0.215\%. Only in one experiment, indications of stirrup rupture and stirrup bending were observed.

- The mode of inclined cracking in all experiments was flexure-shear. Shear-tension cracks developed under higher loads.

\section{ACKNOWLEDGMENTS}

The authors wish to express their gratitude and sincere appreciation to the Dutch Ministry of Infrastructure and the Environment (Rijkswaterstaat) for financing this research work. We are deeply indebted to our colleague Albert Bosman for his work in the laboratory, development of the method to handle the girders, and design of the test setup. Thanks to Jakub Pawlowicz for his work in the laboratory, and for managing the material testing. Many thanks to our colleague Marco Roosen for the preparatory calculations, to René Braam and Cor van der Veen for starting this research project and for their invaluable advice during the preparation and testing stages of this series of experiments, and to former MSc thesis students Nikhil Jayananda, Shozab Mustafa, and Jos Migalski for their prediction calculations. 
$\begin{array}{lll}1 & b_{w} & \text { web width } \\ 2 & d & \text { effective depth }\end{array}$

$3 d_{E C}$ effective depth calculated as weighted average of prestressing steel and mild steel under the

$4 \quad$ centroidal axis

$5 f_{c k, c u b e}$ characteristic cube concrete compressive strength

$6 f_{c m, \text { cube }}$ average cube concrete compressive strength

$7 f_{c t k} \quad$ characteristic splitting tensile strength of the concrete

$8 f_{c t m}$ average splitting tensile strength of the concrete

$9 f_{p 0.1 m}$ average stress in the prestressing steel at a strain of 0.01

$10 f_{p k} \quad$ characteristic tensile strength of prestressing steel

$11 f_{\text {pum }}$ average ultimate strength of the prestressing steel

$12 f_{p w} \quad$ working prestressing level

$13 f_{y m}$ average yield strength of the mild steel

$14 f_{u m}$ average ultimate strength of the mild steel

$15 \quad l_{\text {girder }}$ total length of the girder specimen

$16 l_{\text {span }}$ span length

$17 n_{\text {stirrup }}$ number of stirrups crossing shear crack

$18 \quad s \quad$ stirrup spacing

$19 x$ position in the longitudinal direction with respect to the support at the anchor block of the

$20 \quad$ girder

$21 A_{g} \quad$ gross cross-sectional area of the girder

$22 A_{p} \quad$ area of prestressing reinforcement

$23 A_{p, 1} \quad$ area of one prestressing tendon

$24 A_{s} \quad$ area of tension reinforcement provided by the mild steel

$25 A_{s}$ area of compression reinforcement provided by the mild steel 


\section{$1 \quad A_{s w} \quad$ area of stirrup}

$2 E_{p s m}$ average elastic modulus of prestressing steel

$3 \quad I_{g}$ gross moment of inertia of the girder

$4 \quad F_{\text {crack }}$ load at which flexural cracking occurs

$5 \quad F_{\max }$ maximum load in the experiment

$6 \quad F_{\text {shearcrack }}$ load at which inclined crack is observed

$7 \quad M_{\text {crack }}$ cracking moment

$8 \quad N_{p} \quad$ axial load due to prestressing

$9 \quad V_{a d d}=V_{u}-V_{s c r}$

$10 V_{p} \quad$ sectional shear force due to prestressing at considered section

$11 V_{\text {scr }} \quad$ sectional shear at shear cracking

$12 V_{\text {stirrup }}$ shear capacity provided by $n_{\text {stirrup }}$ stirrups

$13 V_{u} \quad$ sectional shear at failure

$14 \alpha \quad$ angle between shear reinforcement and longitudinal axis (between $45^{\circ}$ and $90^{\circ}$ )

$15 \delta_{\text {fail }}$ maximum deflection in experiment

$16 \varepsilon_{p u} \quad$ ultimate strain of prestressing steel

$17 \rho_{w} \quad$ stirrup reinforcement ratio

$18 \rho_{w, \min }$ minimum stirrup reinforcement ratio

$19 \Delta V_{p} \quad$ shear reinforcement provided by increase in stress in prestressing tendons during test

\section{REFERENCES}

21 AASHTO, 2018, "AASHTO LRFD bridge design specifications, 8th edition," 8th ed. American 22 Association of State Highway and Transportation Officials; Washington, DC,

23 ACI Committee 318, 2008, "Building code requirements for structural concrete (ACI 318-08) and 24 commentary," American Concrete Institute; Farmington Hills, MI, 465 pp.

25 ACI Committee 318, 2019, "Building code requirements for structural concrete (ACI 318-19) and 
1 commentary," American Concrete Institute; Farmington Hills, MI, 503 pp.

2 Amir, S., 2014, "Compressive Membrane Action in Prestressed Concrete Deck Slabs," Ph.D. Thesis,

3 Delft University of Technology, pp. 317.

4 Amir, S., Van der Veen , C., Walraven, J. C. and de Boer, A., 2016, "Experiments on Punching

5 Shear Behavior of Prestressed Concrete Bridge Decks," ACI Structural Journal, V. 113, No. 3, pp. $6 \quad 627-636$.

7 Arthur, P. D., 1965, "The shear strength of pre-tensioned I beams with unreinforced webs," 8 Magazine of Concrete Research, V. 53, pp. 199-210.

9 Bentz, E., 2010, "Response-2000 Manual," University of Toronto.

10 CEN, 2005, "Eurocode 2: Design of Concrete Structures - Part 1-1 General Rules and Rules for 11 Buildings. NEN-EN 1992-1-1:2005," Comité Européen de Normalisation, Brussels, Belgium, 229 12 pp.

13 Code Committee 351001, 2011a, "Assessement of structural safety of an existing structure at repair 14 or unfit for use - Basic Requirements, NEN 8700:2011 (in Dutch)," Civil center for the execution of 15 research and standardization, Dutch Normalisation Institute; Delft, The Netherlands, 56 pp.

16 Code Committee 351001, 2011b, "Assessement of structural safety of an existing structure at repair 17 or unfit for use - Loads, NEN 8701:2011 (in Dutch)," Civil center for the execution of research and 18 standard, Dutch Normalisation Institute; Delft, The Netherlands, 26 pp.

19 Collins, M. P., Xie, L., Mihaylov, B. I. and Bentz, E. C., 2016, "Shear Response of Prestressed 20 Thin-Webbed Continuous Girders," ACI Structural Journal, V. 113, No. 3, 5/1/2016.

21 Collins, M. P. Mitchell, D., 1991, "Prestressed concrete structures," Englew ood Cliffs; NJ: Prentice 22 Hall.

23 De Oude Doos Groningen, 2020, "Helperzoom, viaduct Zuidelijke Ringweg," 24 https://www.google.com/imgres?imgurl=https\%3A\%2F\%2Flookaside.fbsbx.com $\% 2$ Flookaside $\% 2$ 25 Fcrawler\%2Fmedia\%2F\%3Fmedia_id\%3D1224149744405323\&imgrefurl=https\%3A\%2F\%2Fww 
1 w.facebook.com\%2FDeOudeDoosGroningen\%2Fposts $\% 2 F 1224153071071657 \&$ tbnid=wnWk8kw

2 aNq8dMM\&vet=12ahUKEwjc7aLj9r_oAhWSs6QKHfWUCqQQMygKegUIARDYAQ..i\&docid=

3 XdoDw-

4 FVMDSOeM\&w=960\&h=726\&q=helperzoom\%20girder\%20Groningen\& ved=2ahUKEw jc 7aLj9r _oAhWSs6QKHfWUCqQQMygKegUIARDYAQ

6 De Wilder, K., De Roeck, G. and Vandewalle, L., 2018, "Experimental analys is of the shear

7 behaviour of prestressed and reinforced concrete beams," European Journal of Environmental and

8 Civil Engineering, V. 22, No. 3, 2018/03/04, pp. 288-314.

9 Dunkelberg, D., Sneed, L. H., Zilch, K. and Reineck, K.-H., 2018, "The 2015 ACI-DAfStb database of shear tests on slender prestressed concrete beams without stirrups-Overview and evaluation of

11 current design approaches," Structural Concrete, V. 19, No. 6, pp. 1740-1759.

12 Ensink, S. W. H., Van der Veen , C., Hordijk, D. A., Lantsoght, E. O. L., van der Ham, H. and De 13 Boer, A., 2018, "Full-size field test of prestressed concrete T-beam bridge," European Bridge 14 Conference, Edinburgh, Scotland.

15 Ensink, S. W. H., Van der Veen, C. and Hendriks, M. A. N., 2019, "Non-linear analysis of 16 prestressed concrete T-beams," SEMC 2019, Cape Town, South Africa.

17 Herbrand, M. and Classen, M., 2015, "Shear tests on continuous prestressed concrete beams with 18 external prestressing," Structural Concrete, V. 16, No. 3, pp. 428-437.

19 Herbrand, M., Claßen, M. and Adam, V., 2017, "Querkraftversuche an Spannbetondurchlaufträgern 20 mit Rechteck- und I-Querschnitt," Bauingenieur, V. 92, No. 11, pp. 465-473.

21 Hicks, A. B., 1958, "The influence of shear span and concrete strength upon the shear resistance of 22 a pre-tensioned prestressed concrete beam," Magazine of Concrete Research, V. 10, No. 30, pp. $23 \quad 115-122$.

24 Higgs, A., Barr, P. J. and Halling, M. W., 2015, "Comparison of Measured and AASHTO LRFD25 Predicted Residual Prestress Forces, Shear and Flexural Capacities of High-Strength Prestressed- 
1 Concrete Bridge Girders," Journal of Bridge Engineering, V. 20, No. 1, pp. 05014009.

2 Jayananda, N., 2018, "Shear Strengthening of Prestressed Concrete Beams with Ultra High-

3 Performance Fiber Reinforced Composite (UHPFRC) - Numerical analys is by ATENA model,"

$4 \quad$ Ph.D., Delft University of Technology, Delft, the Netherlands, pp. 108.

5 Kar, J. N., 1969, "Shear strength of prestressed concrete beams without web reinforcement,"

6 Magazine of Concrete Research, V. 21, No. 68, pp. 159-170.

7 Koekkoek, R. T., van der Veen, C. and de Boer, A., 2018, "Fatigue Tests on Post-tensioned Bridge

8 Decks," fib symposium 2017. pp. 912-920.

9 Kuchma, D., Kim, K. S., Nagle, T. J., Sun, S. and Hawkins, N. M., 2008, "Shear Tests on High-

10 Strength Prestressed Bulb-Tee Girders: Strengths and Key Observations," Structural Journal, V.

$11 \quad 105$, No. 3, 5/1/2008.

12 Labib, E. L., Dhonde, H. B., Hsu, T. T. C. and Mo, Y. L., 2014, "Shear design of high strength 13 concrete prestressed girders," Frontiers of Structural and Civil Engineering, V. 8, No. 4, December $14 \quad 01$, pp. 373-387.

15 Lantsoght, E. O. L., Braam, C. R. and van der Veen, C., 2019a, "Preparation of shear experiments 16 on prestressed girders Helperzoom," V. Stevin Report 25.5-19-01, Delft University of Technology, 17 Delft, the Netherlands, $41 \mathrm{pp}$.

18 Lantsoght, E. O. L., Koekkoek, R., van der Veen, C. and Sliedrecht, H., 2019b, "Fatigue 19 Assessment of Prestressed Concrete Slab-Between-Girder Bridges," Applied Sciences, V. 9, No. 11, 20 pp. 2312.

21 Lantsoght, E. O. L., Van der Veen , C., Koekkoek, R. T. and Sliedrecht, H., 2019c, "Punching 22 capacity of prestressed concrete bridge decks under fatigue," ACI Structural Journal, V. 116, No. 4, 23 pp. 209-2018.

24 Lantsoght, E. O. L., Van der Veen, C., Koekkoek, R. T. and Sliedrecht, H., 2019d, "Fatigue testing 25 of transversely prestressed concrete decks," ACI Structural Journal, V. 116, No. 4, pp. 143-154. 
1 Lantsoght, E. O. L., Zhang, F., Zarate Garnica, G. I., Yang, Y. and Braam, C. R., 2019e,

2 "Measurement report of prestressed beams from Helperzoom viaduct," Stevin Report 25.5-19-03,

3 Delft University of Technology, Delft, the Netherlands, $75 \mathrm{pp}$.

4 Lantsoght, E. O. L., Zhang, F., Zarate Garnica, G. I., Park, M. K., Mustafa, S., Braam, C. R. and

5 Yang, Y., 2020, "Analysis report of prestressed beams from Helperzoom viaduct," Stevin Report

6 25.5-19-04, Delft University of Technology, Delft, the Netherlands, 158 pp.

7 Laskar, A., Hsu, T. T. C. and Mo, Y. L., 2010, "Shear Strengths of Prestressed Concrete Beams Part

8 1: Experiments and Shear Design Equations," ACI Structural Journal, V. 107, No. 3, May-Jun, pp.

$9 \quad 330-339$.

10 Linthorst, F. G. A. and Teunissen, E. A. H., 2009, "BDX-9002 Materiaalonderzoek 64

11 kunstwerken: 07D-105-01 'Noordelijk viaduct over de spoorlijn Assen-Groningen'," Deventer, the 12 Netherlands, 24 pp.

13 Mahgoub, M. O., 1975, "Shear strength of prestressed concrete beams without web reinforcement," 14 Magazine of Concrete Research, V. 27, No. 93, pp. 219-228.

15 Martin, R. D., Kang, T. H.-K. and Pei, J.-S., 2011, "Experimental and code analyses for shear 16 design of AASHTO prestressed concrete girders," PCI Journal, V. 56, No. 4, pp. 54-74.

17 Mattock, A. H., 1979, "Flexural strength of prestressed concrete sections by programmable 18 calculator," PCI Journal, V. 24, No. 1, pp. 32-54.

19 Movares, 2013, "Quick Scan T- liggers 2013: 07D 105 viaduct Helperzoom volgens RBK versie 1.1

20 ", Utrecht, the Netherlands, 176 pp.

21 Mustafa, S., Lantsoght, E. O. L., Yang, Y. and Sliedrecht, H., in review, "Numerical analysis of 22 prestressed concrete bridge girders failing in shear."

23 Oh, B. H. and Kim, K. S., 2004, "Shear Behavior of Full-Scale Post-Tensioned Prestressed 24 Concrete Bridge Girders," ACI Structural Journal, V. 101, No. 2, 3/1/2004.

25 Osborn, G. P., Barr, P. J., Petty, D. A., Halling, M. W. and Brackus, T. R., 2012, "Residual 
1 Prestress Forces and Shear Capacity of Salvaged Prestressed Concrete Bridge Girders," Journal of

2 Bridge Engineering, V. 17, No. 2, pp. 302-309.

3 Osborn, P., 2010, "Ultimate Shear Capacity and Residual Prestress Force of Full-Scale, Forty-One-

4 Year-Old Prestressed-Concrete Girders," M.Sc. Thesis, Utah State University, pp. 163.

5 Park, M., Lantsoght, E. O. L., Yang, Y. and Sliedrecht, H., in review, "Analys is of shear cpaacity of

6 prestressed concrete bridge girders."

7 Rijkswaterstaat, 2013, "Guidelines Assessment Bridges - assessment of structural safety of an

8 existing bridge at reconstruction, usage and disapproval (in Dutch), RTD 1006:2013 1.1," Utrecht,

9 the Netherlands, $117 \mathrm{pp}$.

10 Roosen, M., 2018, "Shear tension resistance of prestressed beams - Literature review," Delft

11 University of Technology, Delft, the Netherlands.

12 Roosen, M., van der Veen, C. and Hordijk, D., 2018, "Suitability of Shear Tension Code

13 Requirements for the Assessment of Existing Structures Build-Up with Prestressed I- and T-Shape

14 Girders," fib symposium 2017,pp. 786-793.

15 Roosen, M. A., Van der Veen , C., Hordijk, D. A. and Hendriks, M. A. N., 2019a, "Shear tension

16 resistance of prestressed girders with a low stirrup ratio," SEMC 2019, Cape Town, South Africa.

17 Roosen, M. A., Van der Veen, C., Hordijk, D. A. and Hendriks, M. A. N., 2019b, "Resistance to 18 diagonal tension cracking of single span prestressed girders," SEMC 2019, Cape Town, South 19 Africa.

20 Ross, B. E., Hamilton, H. R. and Consolazio, G. R., 2015, "Experimental Study of End Region 21 Detailing and Shear Behavior of Concrete I-Girders," Journal of Bridge Engineering, V. 20, No. 6, 22 pp. 04014087.

23 Scholz, H., 1990, "Ductility, redistribution, and hyperstatic moments in partially prestressed 24 members," ACI Structural Journal, V. 87, No. 3, pp. 341-349.

25 Schramm, N. and Fischer, O., 2019, "Influence of no longer permitted stirrup types on the shear 
1 capacity - experimental investigations on prestressed continuous beam subsystems," SEMC 2019,

2 Cape Town, South Africa.

3 Shahawy, M. A. and de Batchelor, B., 1996, "Shear Behavior of Full-Scale Prestressed Concrete

4 Girders: Comparison Between AASHTO Specifications and LRFD Code," PCI Journal, V. 41, No.

$5 \quad 3$, pp. 48-62.

6 Shen, J., Yurtdas, I., Diagana, C. and Li, A., 2015, "Experimental investigation on the shear

7 performance of prestressed self-compacting concrete beams without stirrups," Materials and

8 Structures, V. 48, No. 5, May 01, pp. 1291-1302.

9 Vecchio, F. J., Collins, M. P., 1986, "The modified compression-field the ory for re inforced concrete

10 elements subjected to shear," ACI Journal, V. 83, No. 2, pp. 219-231.

11 Vergeer, M. C., 2019, "Shear tension resistance of prestressed concrete beams with shear 12 reinforcement - Based on the MCFT," M.Sc. Thesis, Delft University of Technology, Delft, the 13 Netherlands, pp.

14 Vill, M., Torghele, H., Brunner, H. and Kollegger, J., 2011, "Zerstöre nde Belastungsversuche zur

15 Untersuchung des Schubtragverhaltens von vorgespannten Trägern einer Straßenbrücke," Beton16 und Stahlbetonbau, V. 106, No. 4, pp. 241-249.

17 Zwicky, D. and Vogel, T., 2000, "Bruchversuche an ausgebauten Brückenträgern aus Spannbeton," 18 ETH Zürich, Zürich, Switzerland, 172 pp.

19 Zwicky, D., 2002, "Zur Tragfähigkeit stark vorgespannter Betonbalken," PhD thesis, ETH Zürich, $20 \quad$ pp. 239. 
List of Tables

3 Table 1 - Measured dimensions of girders after sawing. Conversion: $1 \mathrm{~m}=3.3 \mathrm{ft}$

6 Table 2. Overview of results of prestressing stress, determined with different approaches, where

7 the $\%$ refers to the percentage of the originally expected working prestressing level. Conversion: 1

$8 \mathrm{~m}=3.3 \mathrm{ft}, 1 \mathrm{kN}=0.225 \mathrm{kip}, 1 \mathrm{kNm}=0.738 \mathrm{kip}-\mathrm{ft}, 1 \mathrm{MPa}=145 \mathrm{psi}$.

9 Table 3. Overview of experimental results. Conversion $1 \mathrm{~m}=3.3 \mathrm{ft}, 1 \mathrm{~mm}=0.04 \mathrm{in} ., 1 \mathrm{kN}=0.225$

10 kip.

11

12 Table 4. Overview of test results in terms of sectional shear. Conversion: $1 \mathrm{kN}=0.225 \mathrm{kip}, 1 \mathrm{~m}=$ $13 \quad 3.3 \mathrm{ft}$.

Table 1 - Measured dimensions of girders after sawing. Conversion: $1 \mathrm{~m}=3.3 \mathrm{ft}$

\begin{tabular}{|l|l|l|l|l|l|}
\hline Specimen & $\begin{array}{l}\text { Length } \\
(\mathrm{m})\end{array}$ & $\begin{array}{l}\text { Width east } \\
(\mathrm{m})\end{array}$ & $\begin{array}{l}\text { Width west } \\
(\mathrm{m})\end{array}$ & $\begin{array}{l}\text { Width middle } \\
(\mathrm{m})\end{array}$ & $\begin{array}{l}\text { Height } \\
(\mathrm{m})\end{array}$ \\
\hline HPZ01 & 10.51 & 0.965 & 0.940 & 0.960 & 1.110 \\
\hline HPZ02 & 11.10 & 1.060 & 0.960 & 1.043 & 1.110 \\
\hline HPZ03 & 12.28 & 0.990 & 0.950 & 0.985 & 1.110 \\
\hline HPZ04 & 12.88 & 0.960 & 1.010 & 0.928 & 1.110 \\
\hline
\end{tabular}

15

16

Table 2. Overview of results of prestressing stress, determined with different approaches,

18 where the \% refers to the percentage of the originally expected working prestressing level.

Conversion: $1 \mathrm{~m}=3.3 \mathrm{ft}, 1 \mathrm{kN}=0.225 \mathrm{kip}, 1 \mathrm{kNm}=0.738 \mathrm{kip}-\mathrm{ft}, 1 \mathrm{MPa}=145 \mathrm{psi}$.

\begin{tabular}{|c|c|c|c|c|c|c|c|c|c|c|c|c|c|c|}
\hline & & \multicolumn{2}{|c|}{ Test results } & \multicolumn{2}{|c|}{ LVDT results } & \multicolumn{3}{|c|}{$\begin{array}{c}\text { Load-deflection } \\
\text { results }\end{array}$} & \multicolumn{6}{|c|}{\begin{tabular}{|c|c|}
$\begin{array}{c}\text { Direct measurement } \\
\text { results }\end{array}$ & $\begin{array}{c}\text { Sectional anal ysis } \\
\text { results }\end{array}$ \\
\end{tabular}} \\
\hline & $\begin{array}{r}x \\
(\mathrm{~m}) \\
\end{array}$ & $\begin{array}{l}F_{\text {crack }} \\
(\mathrm{kN})\end{array}$ & $\begin{array}{l}M_{\text {crack }} \\
(\mathrm{kNm})\end{array}$ & $\begin{array}{l}F_{\text {crack }} \\
(\mathrm{kN})\end{array}$ & & $\begin{array}{c}f_{p w} \\
(\mathrm{MPa}) \\
\end{array}$ & $\begin{array}{c}N_{p} \\
(\mathrm{kN}) \\
\end{array}$ & $\%$ & $\begin{array}{c}f_{p w} \\
(\mathrm{MPa})\end{array}$ & $\begin{array}{c}N_{p} \\
(\mathrm{kN})\end{array}$ & $\%$ & $\begin{array}{c}f_{p w} \\
(\mathrm{MPa}) \\
\end{array}$ & $\begin{array}{c}N_{p} \\
(\mathrm{kN})\end{array}$ & $\%$ \\
\hline & 903 & & 2094 & & & 608 & 1970 & & & & & 695 & 2569 & 80 \\
\hline
\end{tabular}




\begin{tabular}{|l||c|c|c|c|c|c|c|c|c|c|c|c|c|c|}
\hline HPZ02 & 2.903 & 1001 & 2191 & 1032 & 2209 & 651 & 2119 & 75 & 494 & 1826 & 57 & 725 & 2680 & 83 \\
\hline HPZ03 & 4.4 & 1025 & 2576 & 1025 & 2582 & 651 & 2712 & 75 & 925.6 & 3849 & 107 & 700 & 2911 & 81 \\
\hline HPZ04 & 4.4 & 1100 & 2745 & 1108 & 2780 & 712 & 2974 & 82 & 528 & 2194 & 61 & 780 & 3243 & 90 \\
\hline
\end{tabular}

2 Table 3. Overview of experimental results. Conversion $1 \mathrm{~m}=3.3 \mathrm{ft}, 1 \mathrm{~mm}=0.04 \mathrm{in}$., $1 \mathrm{kN}=$

0.225 kip.

\begin{tabular}{|l||l|l|l|l|}
\hline & HPZO1 & HPZ02 & HPZ03 & HPZ04 \\
\hline Date & $27 / 06 / 2019$ & $12 / 09 / 2019$ & $14 / 11 / 2019$ & $16-17 / 12 / 2019$ \\
\hline $\boldsymbol{l}_{\text {girder }}$ & $10.51 \mathrm{~m}$ & $11.1 \mathrm{~m}$ & $12.28 \mathrm{~m}$ & $12.88 \mathrm{~m}$ \\
\hline $\boldsymbol{l}_{\text {span }}$ & $9.6 \mathrm{~m}$ & $9.6 \mathrm{~m}$ & $9.6 \mathrm{~m}$ & $9.6 \mathrm{~m}$ \\
\hline $\boldsymbol{a}$ & $2903 \mathrm{~mm}$ & $2903 \mathrm{~mm}$ & $4400 \mathrm{~mm}$ & $4400 \mathrm{~mm}$ \\
\hline $\boldsymbol{d}_{\boldsymbol{E} \boldsymbol{C}}$ & $806 \mathrm{~mm}$ & $806 \mathrm{~mm}$ & $898 \mathrm{~mm}$ & $898 \mathrm{~mm}$ \\
\hline $\boldsymbol{a} / \boldsymbol{d}_{\boldsymbol{E} \boldsymbol{C}}$ & 3.6 & 3.6 & 4.9 & 4.9 \\
\hline $\boldsymbol{F}_{\text {crack }}$ & $965 \mathrm{kN}$ & $1001 \mathrm{kN}$ & $1025 \mathrm{kN}$ & $1100 \mathrm{kN}$ \\
\hline $\boldsymbol{F}_{\text {shearcrack }}$ & $1344 \mathrm{kN}$ & $1299 \mathrm{kN}$ & $1250 \mathrm{kN}$ & $1450 \mathrm{kN}$ \\
\hline $\boldsymbol{F}_{\text {max }}$ & $1893 \mathrm{kN}$ & $1849 \mathrm{kN}$ & $1990 \mathrm{kN}$ & $2380 \mathrm{kN}$ \\
\hline $\boldsymbol{\delta}_{\text {fail }}$ & $51.5 \mathrm{~mm}$ & $39.7 \mathrm{~mm}$ & $60.9 \mathrm{~mm}$ & $68.6 \mathrm{~mm}$ \\
\hline Failure mode & FS + SC & FS $+\mathrm{SC}$ & FS + CC & FS + CF \\
\hline
\end{tabular}

Table 4. Overview of test results in terms of sectional shear. Conversion: $1 \mathrm{kN}=0.225 \mathrm{kip}, 1$

$$
\mathrm{m}=3.3 \mathrm{ft} \text {. }
$$

\begin{tabular}{|c|c|c|c|c|c|c|c|c|}
\hline & $\begin{array}{l}x \\
(\mathrm{~m})\end{array}$ & $\begin{array}{l}V_{p} \\
(\mathrm{kN})\end{array}$ & $\begin{array}{l}V_{u} \\
(\mathrm{kN})\end{array}$ & $\begin{array}{l}V_{s c r} \\
(\mathrm{kN}) \\
\end{array}$ & $\begin{array}{l}V_{\text {add }} \\
(\mathrm{kN})\end{array}$ & $n_{\text {stirrup }}$ & $\begin{array}{l}V_{\text {stirrup }} \\
(\mathrm{kN})\end{array}$ & $\begin{array}{l}\Delta V_{p} \\
(\mathrm{kN})\end{array}$ \\
\hline \multirow[t]{2}{*}{ HPZ01 } & 2.903 & -297 & 1048 & 665 & \multirow[t]{2}{*}{383} & \multirow[t]{2}{*}{5} & \multirow[t]{2}{*}{357} & \multirow[t]{2}{*}{52} \\
\hline & 1.828 & -176 & 1183 & 801 & & & & \\
\hline \multirow[t]{2}{*}{ HPZ02 } & 2.903 & -310 & 1004 & 620 & \multirow[t]{2}{*}{384} & \multirow[t]{2}{*}{5} & \multirow[t]{2}{*}{357} & \multirow[t]{2}{*}{36} \\
\hline & 1.873 & -184 & 1143 & 761 & & & & \\
\hline \multirow[t]{2}{*}{ HPZ03 } & 4.400 & -356 & 725 & 324 & \multirow[t]{2}{*}{401} & \multirow[t]{2}{*}{5} & \multirow[t]{2}{*}{357} & \multirow[t]{2}{*}{160} \\
\hline & 3.460 & -251 & 841 & 440 & & & & \\
\hline \multirow[t]{2}{*}{ HPZ04 } & 4.400 & -396 & 894 & 345 & \multirow[t]{2}{*}{503} & \multirow[t]{2}{*}{5} & \multirow[t]{2}{*}{357} & \multirow[t]{2}{*}{117} \\
\hline & 2.832 & -333 & 976 & 435 & & & & \\
\hline
\end{tabular}




\section{List of Figures}

2 Figure 1. View of the Helperzoom bridge, left: shortly after construction (De Oude Doos Groningen,

3 2020), and right: shortly before demolition (Jayananda, 2018).

4 Figure 2. Cross-section of the girder: left, section A-A' and right, section at midspan B-B'. All

5 dimensions in $\mathrm{mm}$. Conversion: $1 \mathrm{~mm}=0.039 \mathrm{in}$.

6 Figure 3. Side view of girder (from support to midspan), showing tendon layout, position of

7 hammerhead and tapering part, as well as position of cross-beam. Cross-sections A-A' and B-B' are

8 indicated on this sketch and refer to Figure 2. All dimensions in $\mathrm{mm}$. Conversion: $1 \mathrm{~mm}=0.039 \mathrm{in}$.

9 Figure 4. Measured stress-strain diagrams of nine successful sample tests, as well as simplified

10 bilinear diagram. The simplified bilinear diagram uses a first branch with stiffness $E=185 \mathrm{GPa}$

$11(26,830 \mathrm{ksi})$ and the second branch with the equation displayed in the graph. Conversion: $1 \mathrm{MPa}=$ 12145 psi.

13 Figure 5. Detail of prestressing strands: sketch and photograph. Conversion: $1 \mathrm{~mm}=0.04$ in.

14 Figure 6. Test setup: (a) Overview photograph of test setup in laboratory, (b) technical drawing of 15 side view.

16 Figure 7. Detail of support conditions.

17 Figure 9. Loading graph used during HPZ01. Conversion: $1 \mathrm{kN}=0.445$ kip.

18 Figure 8. External transverse prestressing applied to avoid possible failure on the unwanted side.

19 Figure shows HPZ03.

20 Figure 10. Sensor plan for beam HPZ04 showing LVDTs, lasers, AE sensors, and smart aggregates

21 SA). All positions in $\mathrm{mm}$. Conversion: $1 \mathrm{~mm}=0.04 \mathrm{in}$.

22 Figure 11. Development of cracks and final failure of HPZ01.

23 Figure 12. Development of cracks and final failure of HPZ02.

24 Figure 13. Development of cracks and final failure of HPZ03.

25 Figure 14. Development of cracks and final failure of HPZ04. 
1 Figure 15. Load-displacement diagrams of experiments. Conversion: $1 \mathrm{kN}=0.225 \mathrm{kip}, 1 \mathrm{~mm}=$ 20.04 in.
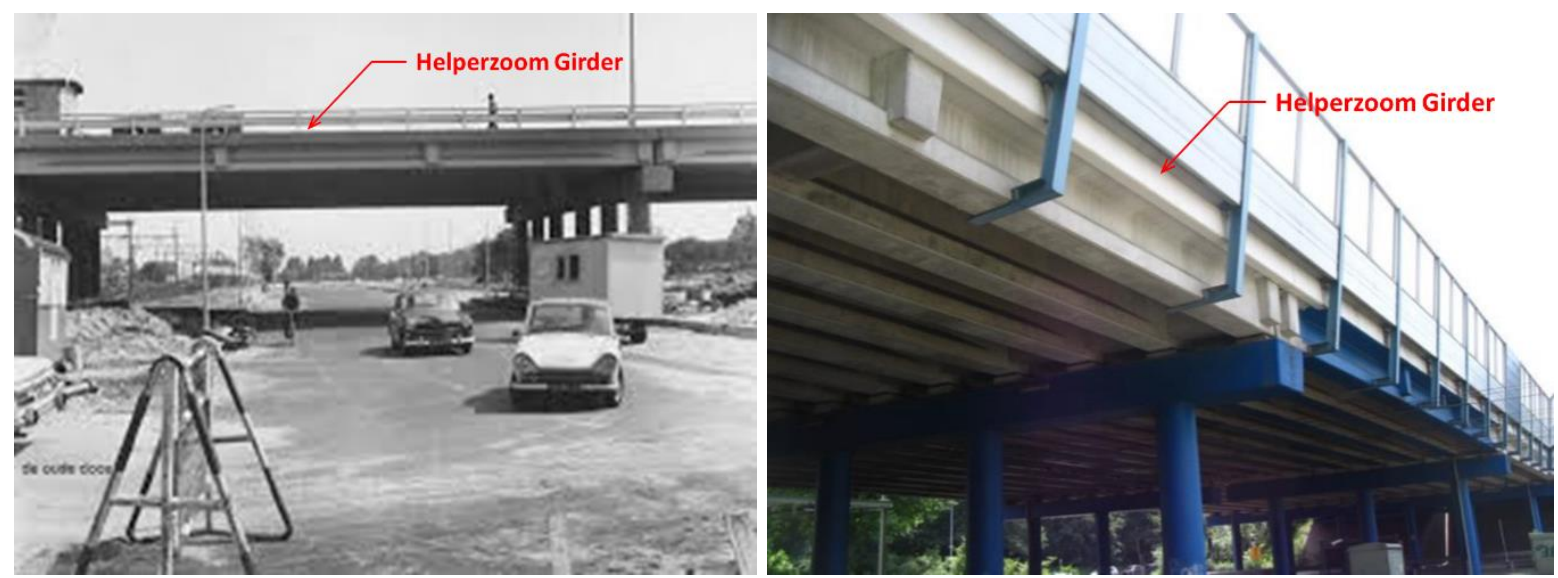

Figure 1. View of the Helperzoom bridge, left: shortly after construction (De Oude Doos
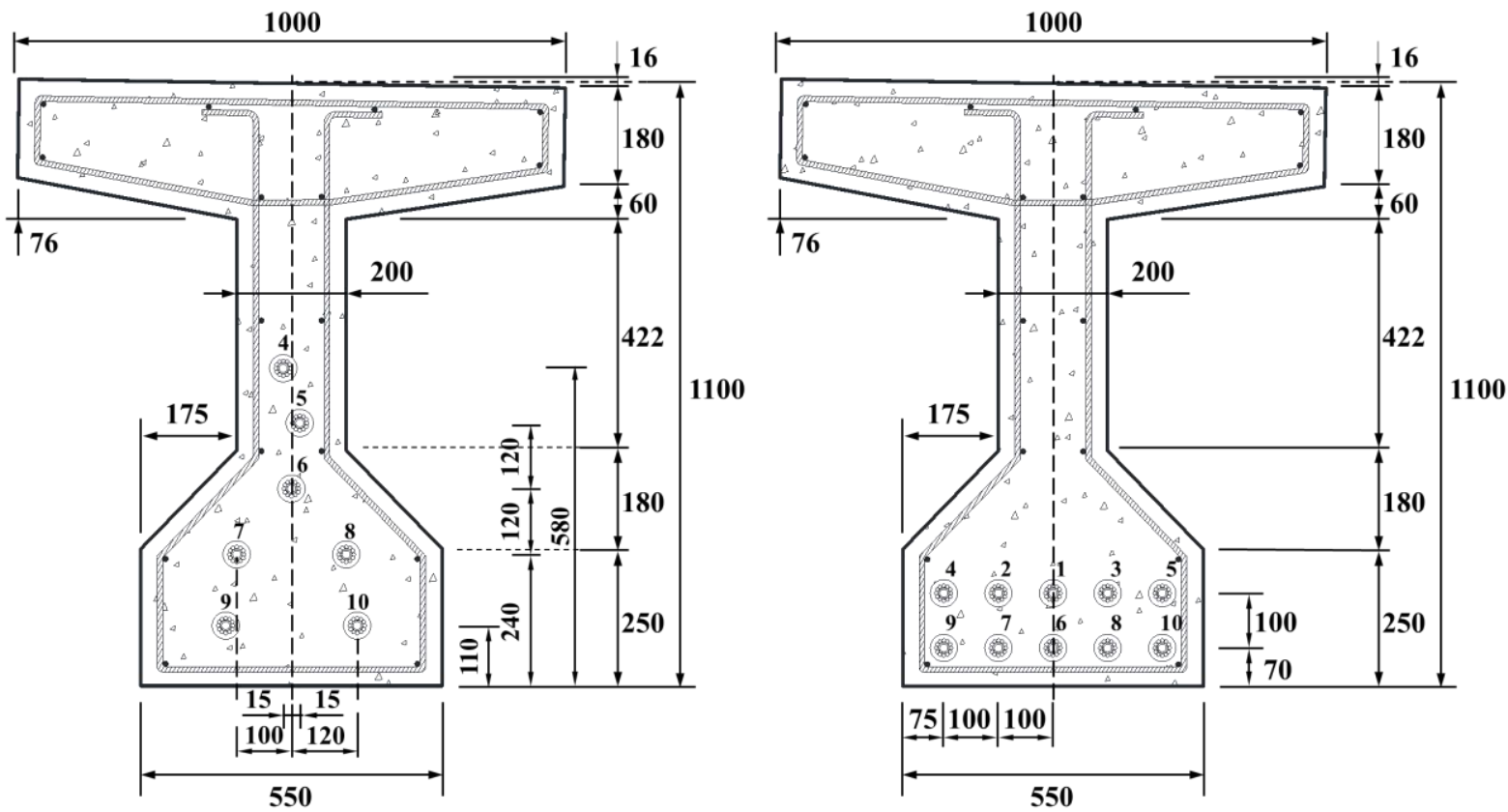

9 Figure 2. Cross-section of the girder: left, section A-A' and right, section at mids pan B-B'. All

10 dimensions in $\mathbf{m m}$. Conversion: $1 \mathbf{~ m m}=\mathbf{0 . 0 3 9}$ in. 


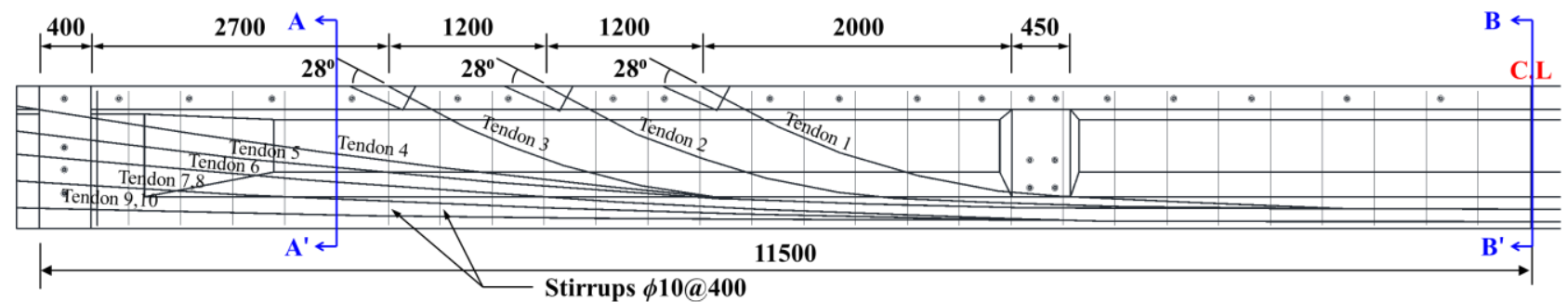

2 Figure 3. Side view of girder (from support to midspan), showing tendon layout, position of hammerhead and tape ring part, as well as position of cross-beam. Cross-sections A-A' and BB' are indicated on this sketch and refer to Figure 2. All dimensions in mm. Conversion: 1 $5 \mathbf{m m}=\mathbf{0 . 0 3 9}$ in.

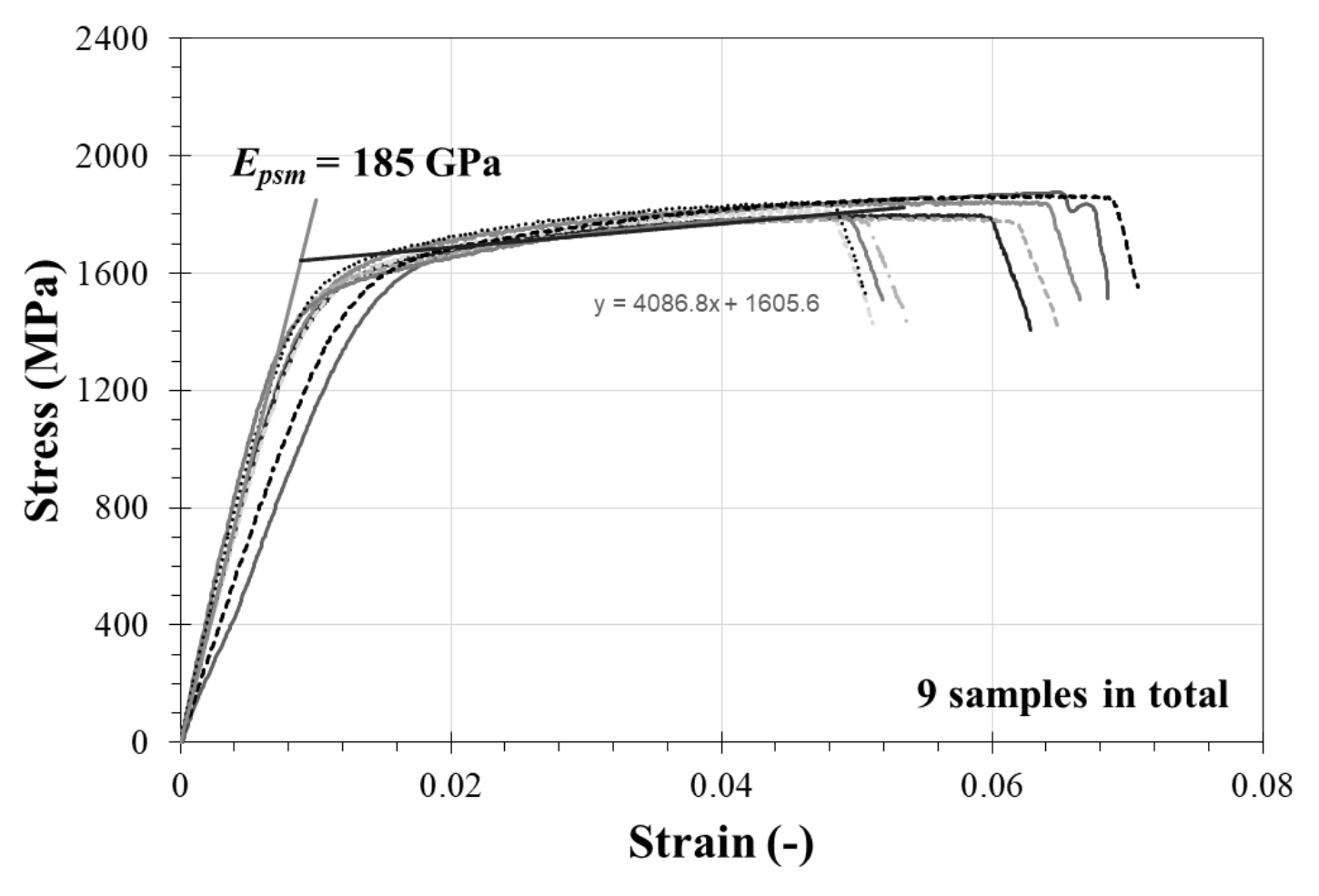

7 Figure 4. Meas ured stress-strain diagrams of nine successful sample tests, as well as simplified bilinear diagram. The simplified bilinear diagram uses a first branch with stiffness $E=185$

9 GPa (26,830 ksi) and the second branch with the equation displayed in the graph. Conversion: $1 \mathrm{MPa}=145$ psi. 

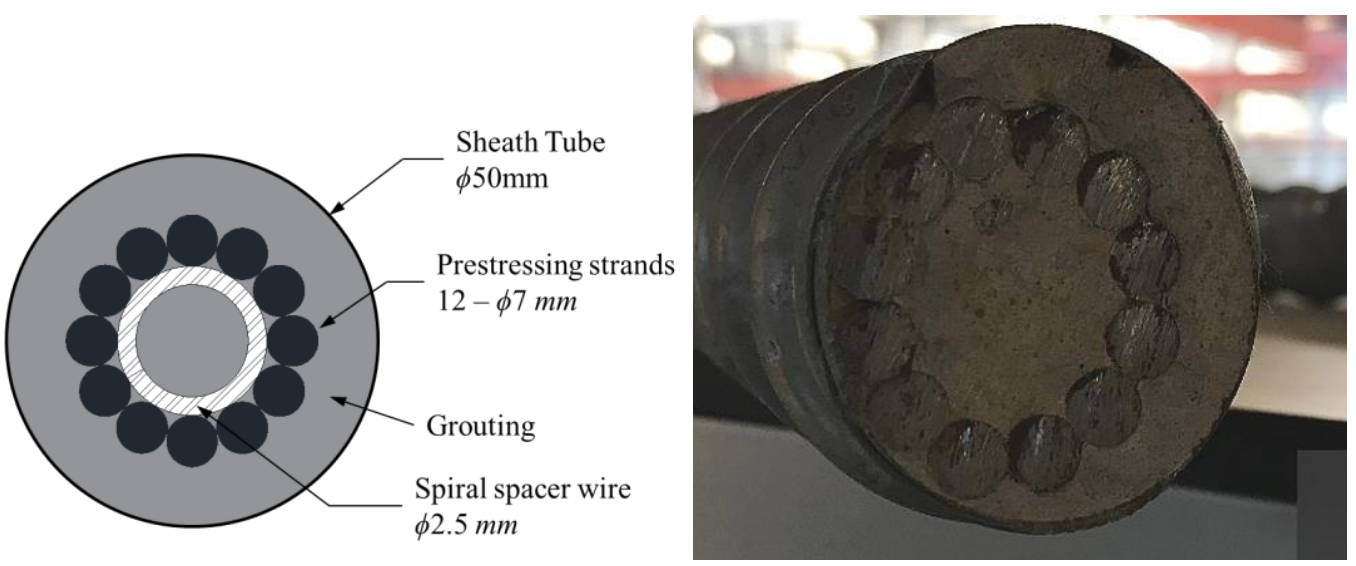

2 Figure 5. Detail of prestressing strands: sketch and photograph. Conversion: $1 \mathrm{~mm}=0.04 \mathrm{in}$. 


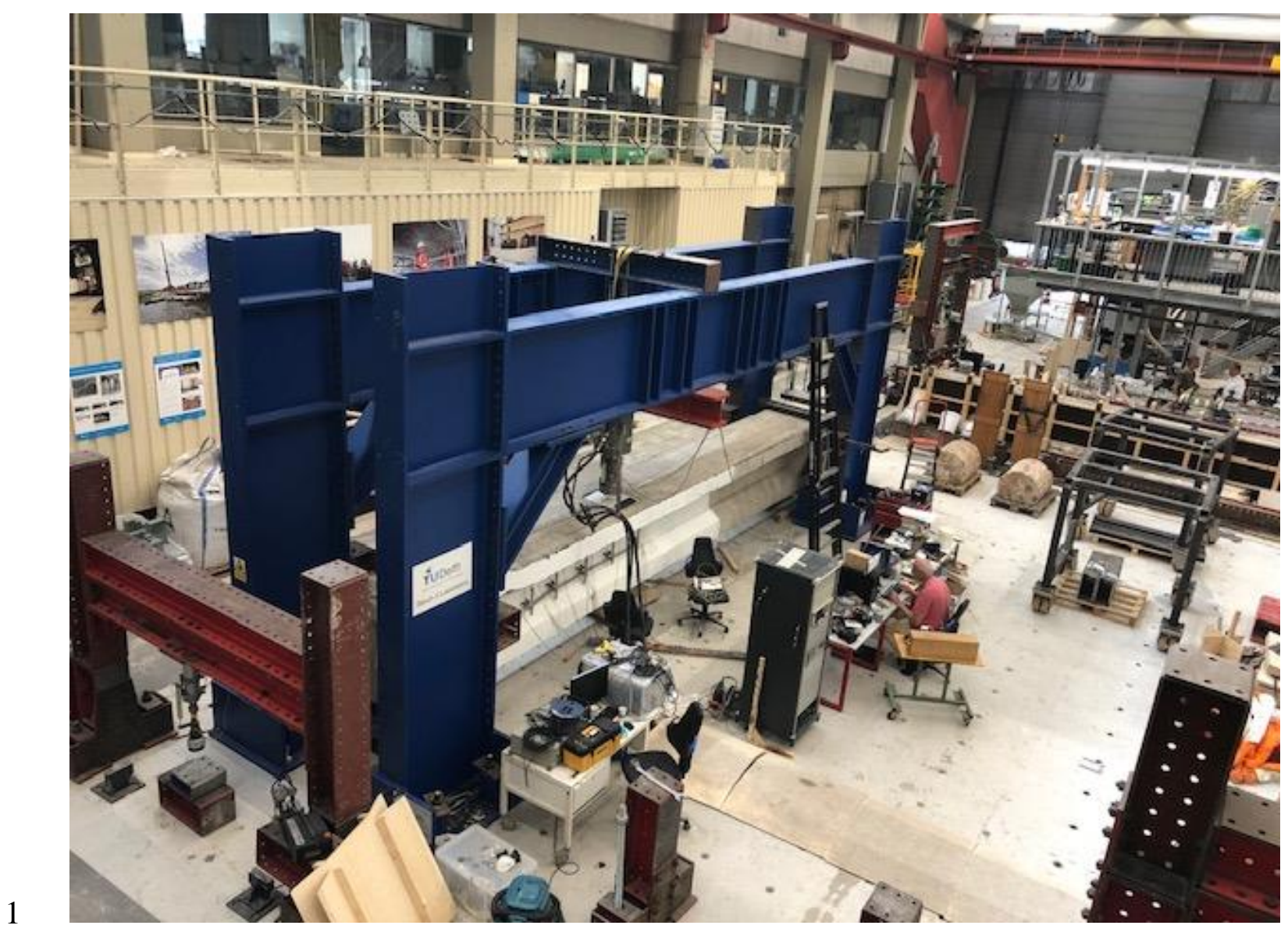

2 (a)

3

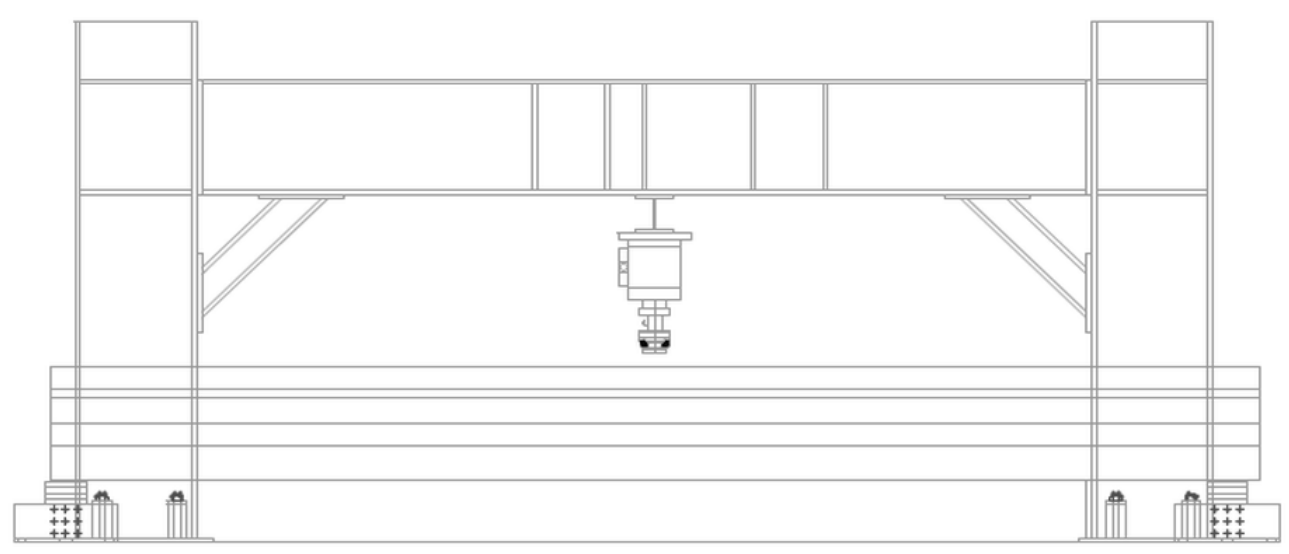

4 (b)

5 Figure 6. Test setup: (a) Overview photograph of test setup in laboratory, (b) technical

6 drawing of side view. 


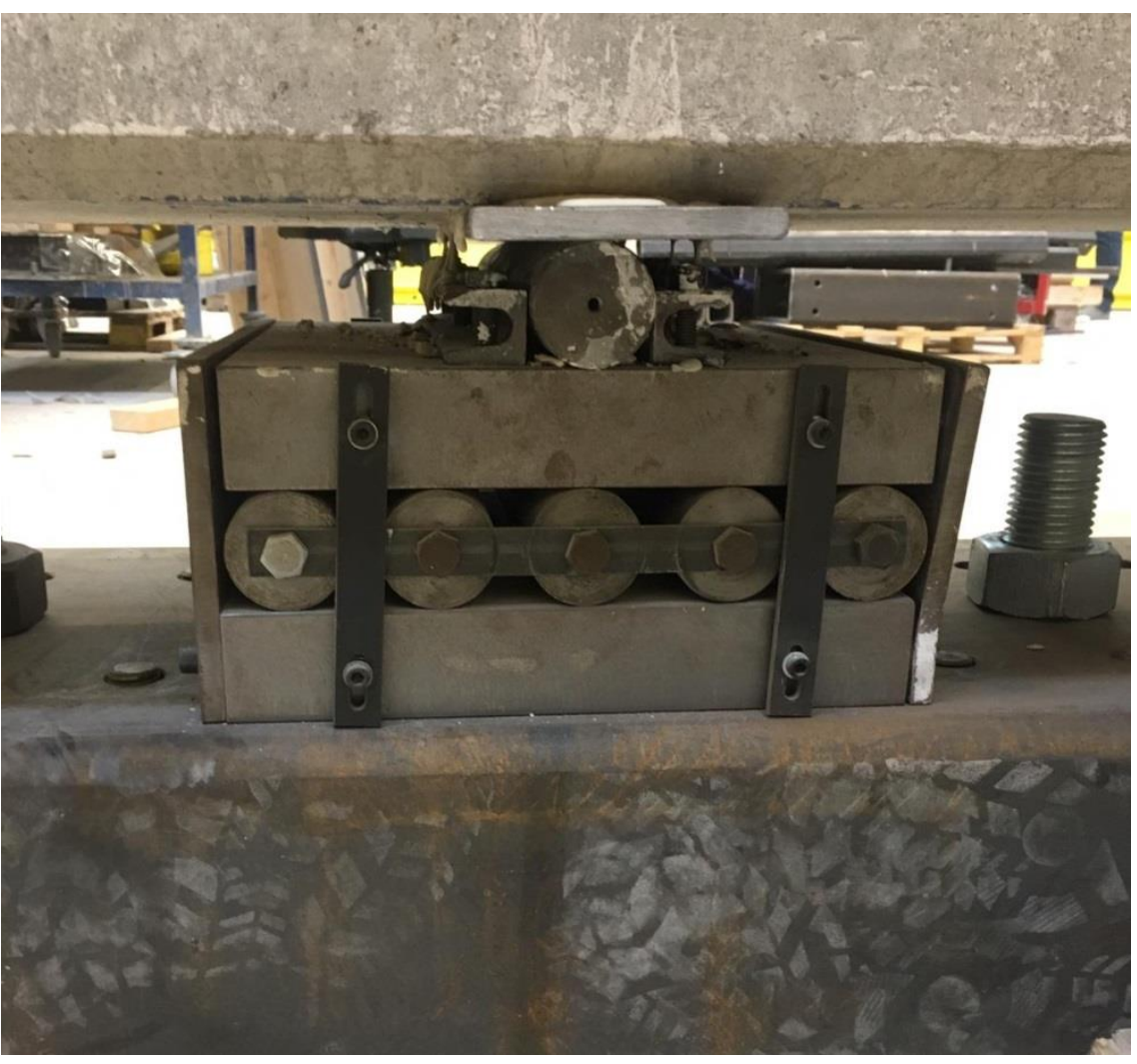

2 Figure 7. Detail of support conditions.

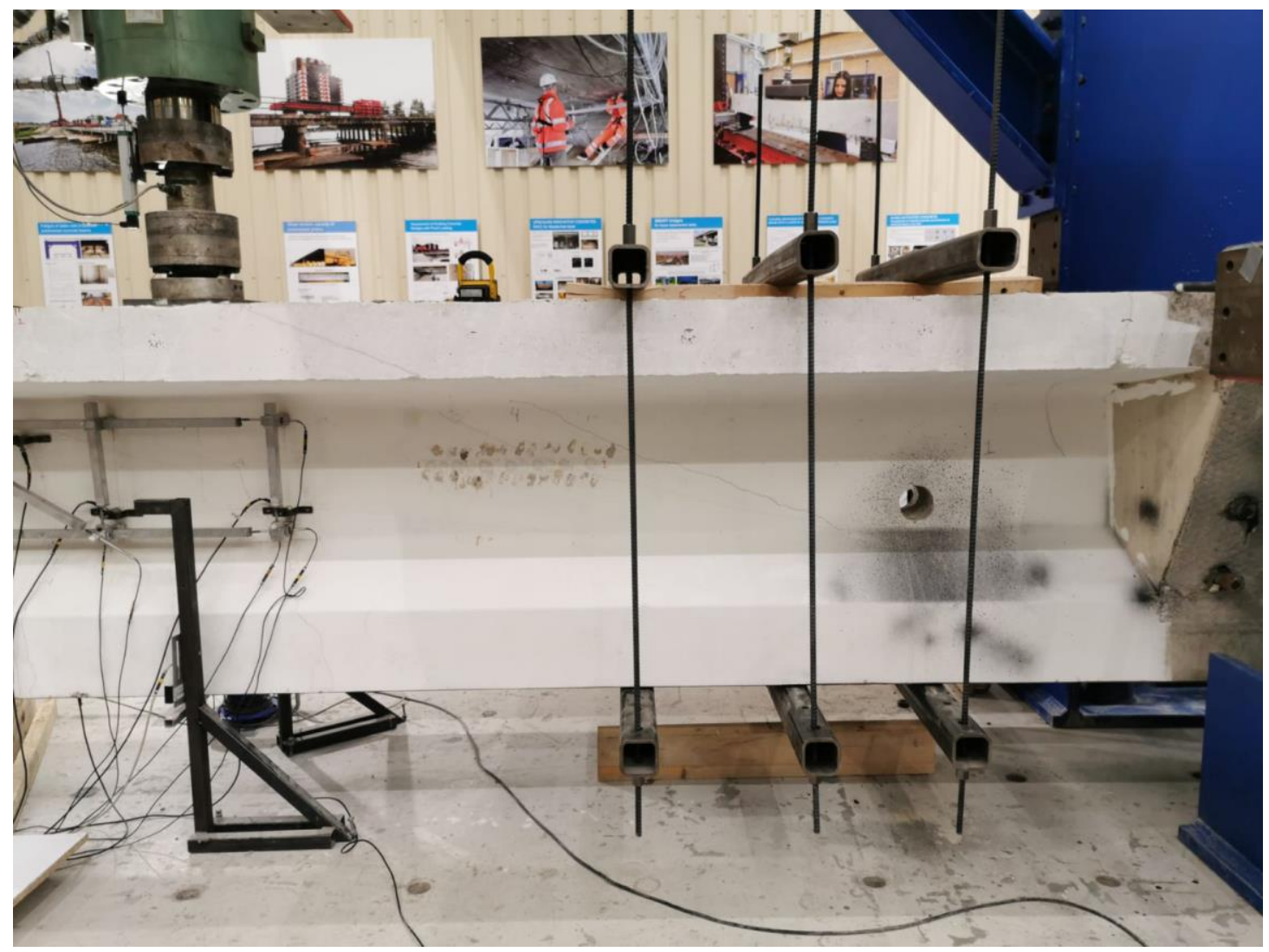

4 Figure 8. External trans verse prestressing applied to avoid possible failure on the unwanted 
1 side. Figure shows HPZ03.

2

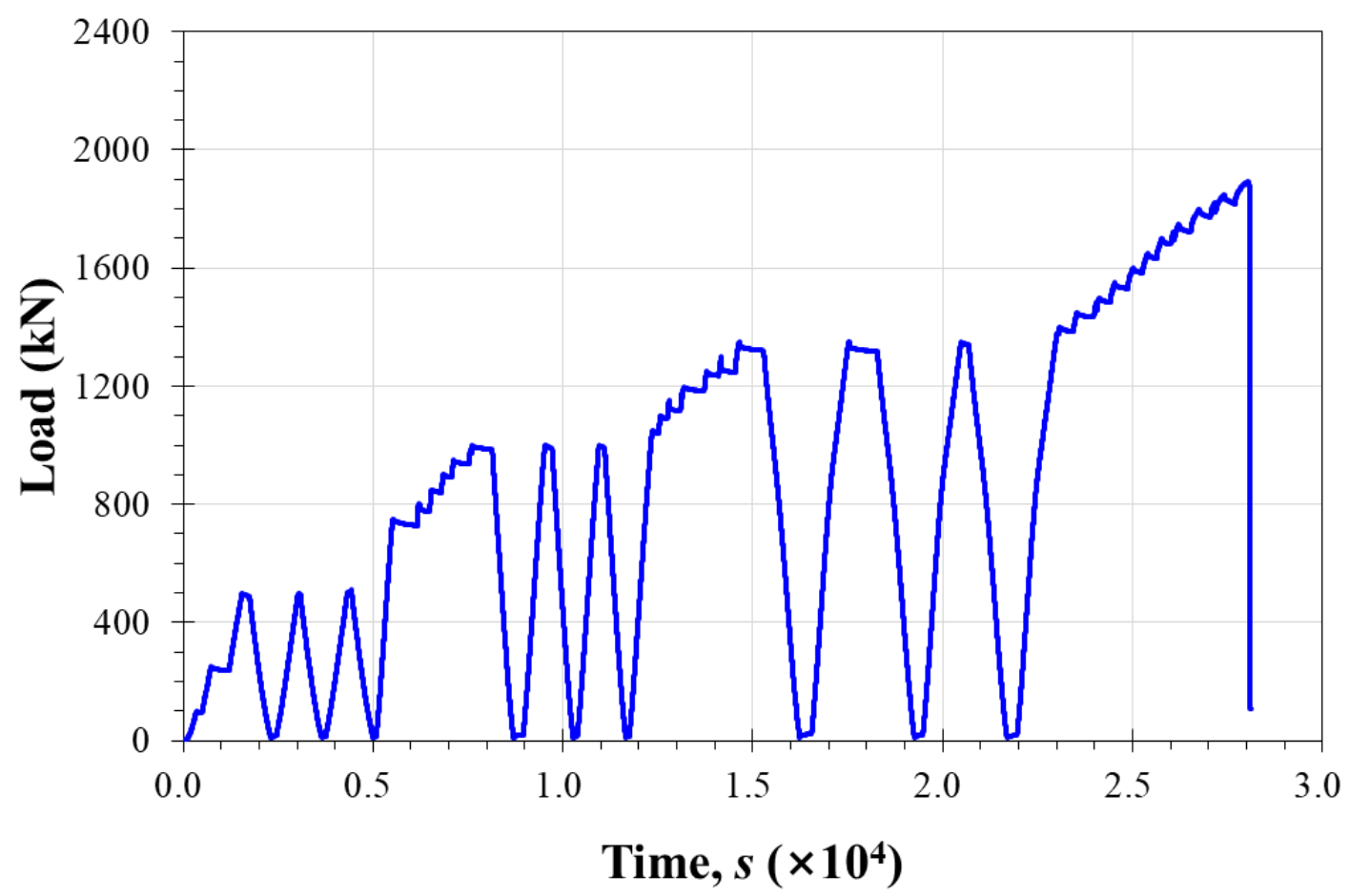

3

4 Figure 9. Loading graph used during HPZ01. Conversion: 1 kN = 0.445 kip.

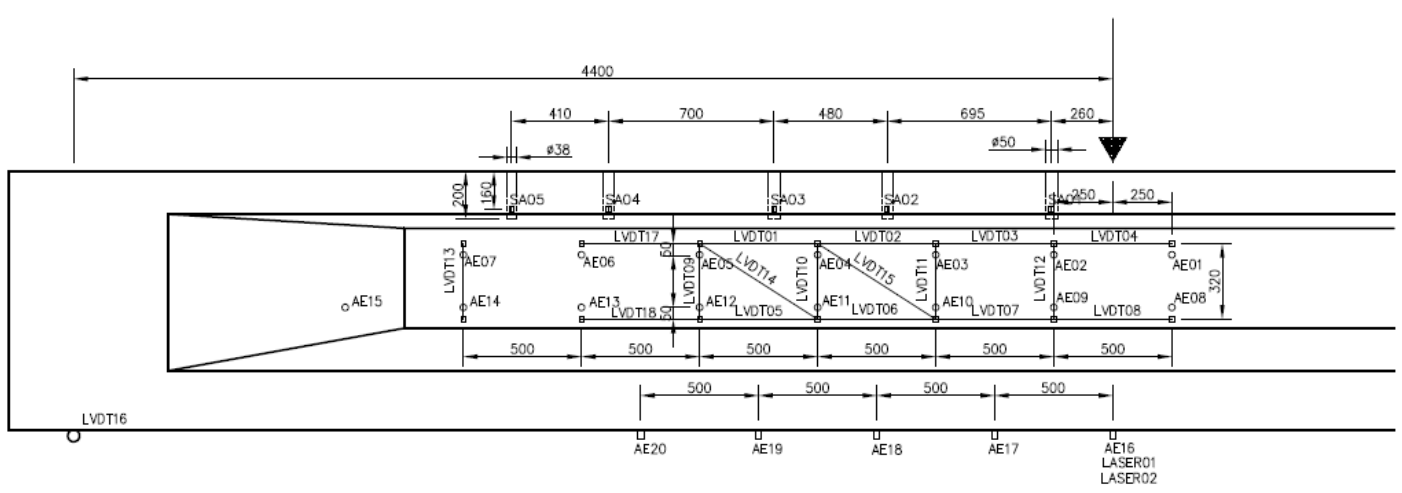

5

6 Figure 10. Sensor plan for beam HPZ04 showing LVDTs, lasers, AE sensors, and smart 7 aggregates SA). All positions in $\mathrm{mm}$. Conversion: $1 \mathrm{~mm}=0.04 \mathrm{in}$. 


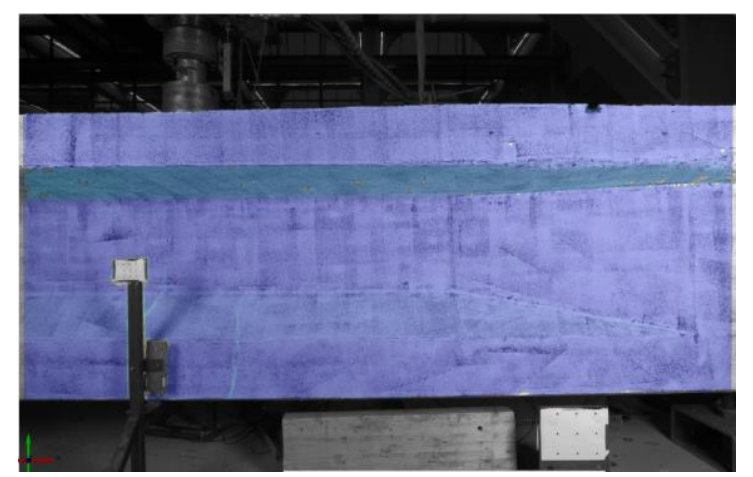

$1150 \mathrm{kN}=259 \mathrm{kip}$

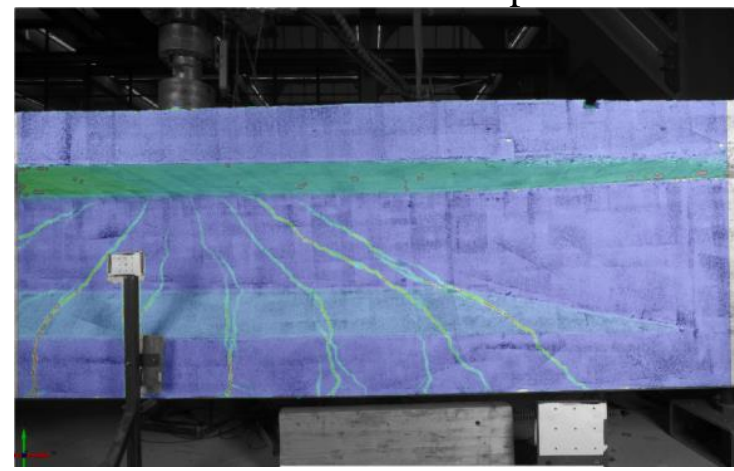

$1550 \mathrm{kN}=349 \mathrm{kip}$

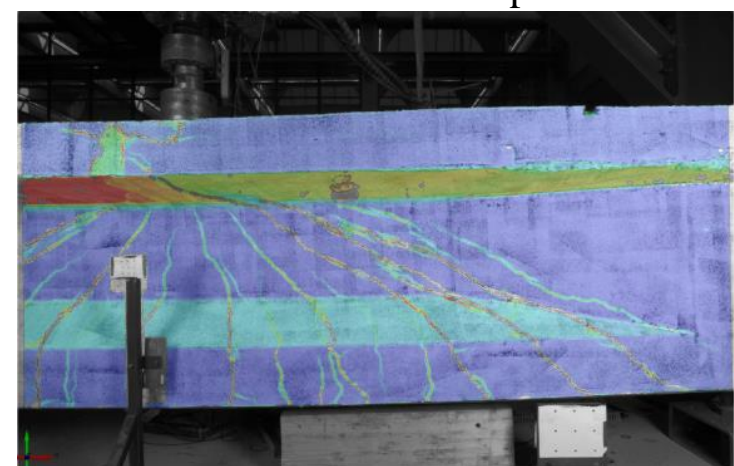

$1892 \mathrm{kN}=426 \mathrm{kip}$

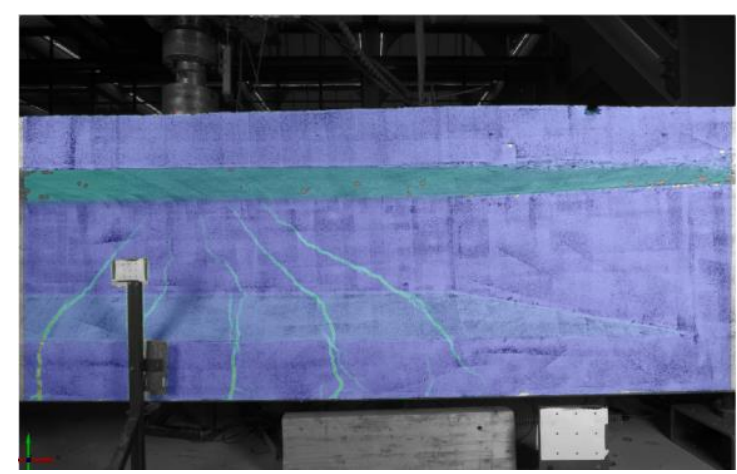

$1350 \mathrm{kN}=304$ kip

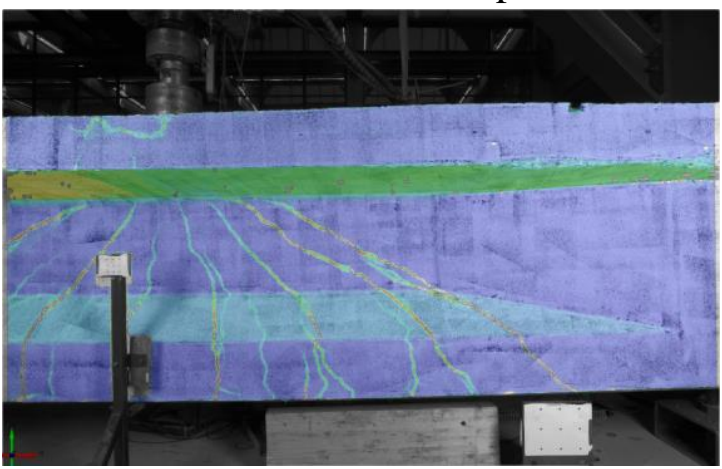

$1775 \mathrm{kN}=399 \mathrm{kip}$

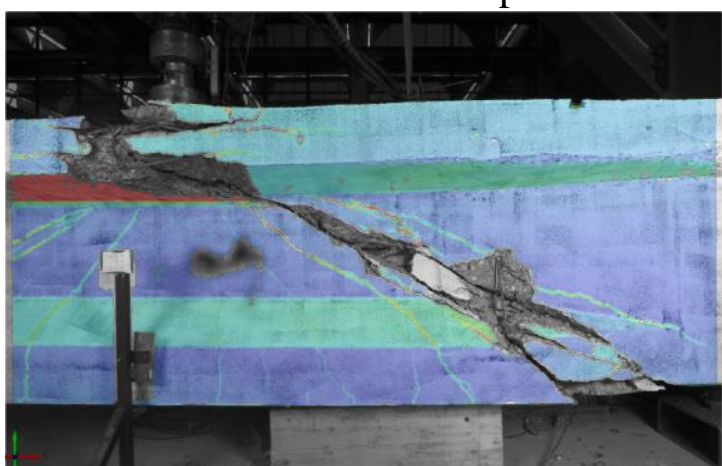

Shear-compression failure

Figure 11. Development of cracks and final failure of HPZ01. 


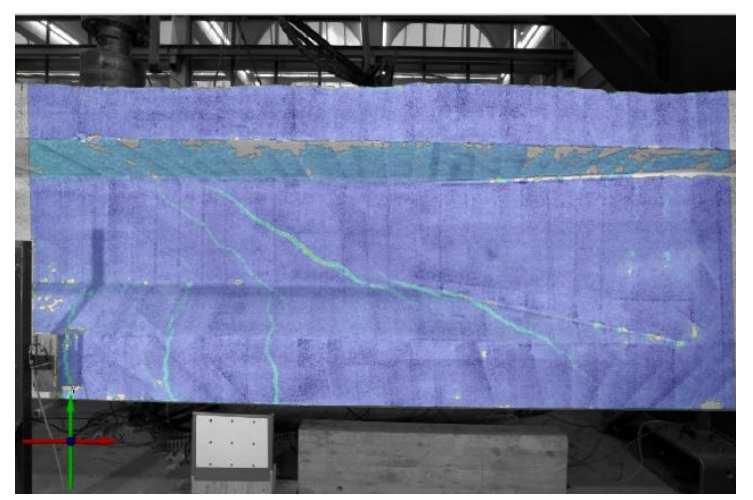

$1350 \mathrm{kN}=304$ kip

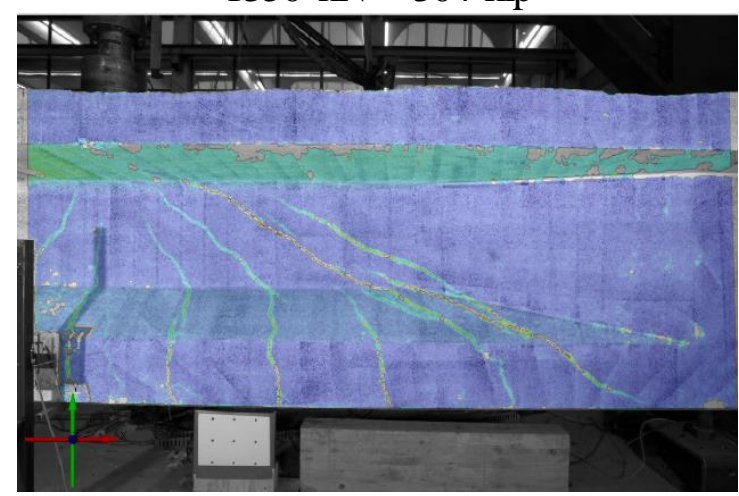

$1750 \mathrm{kN}=394 \mathrm{kip}$

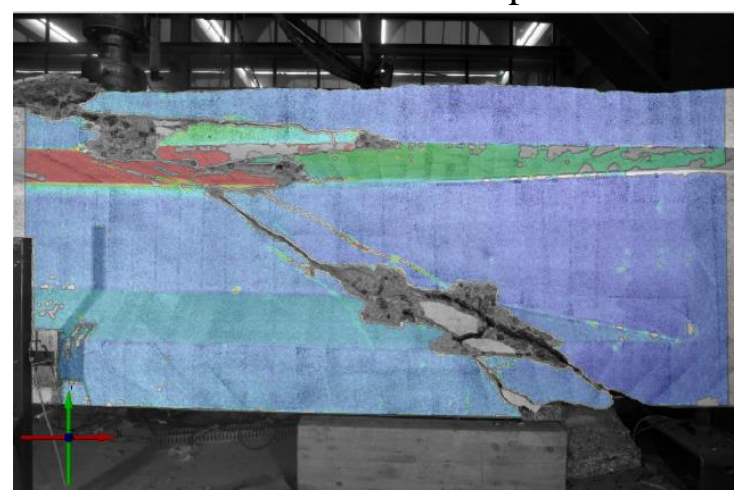

Shear-compression failure

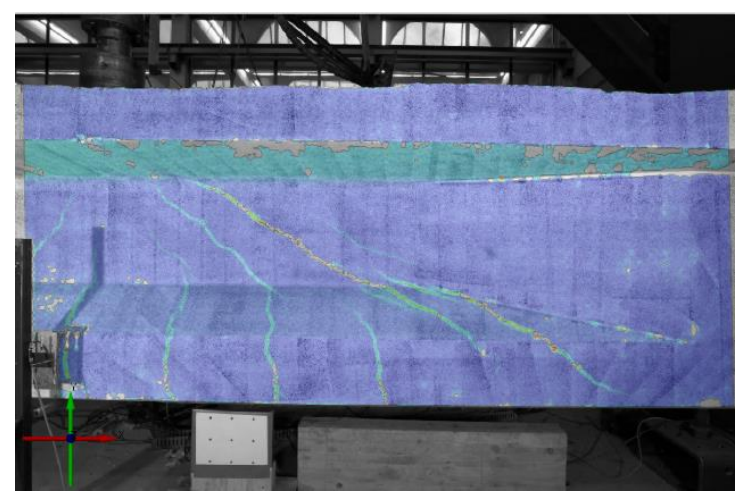

$1550 \mathrm{kN}=349 \mathrm{kip}$

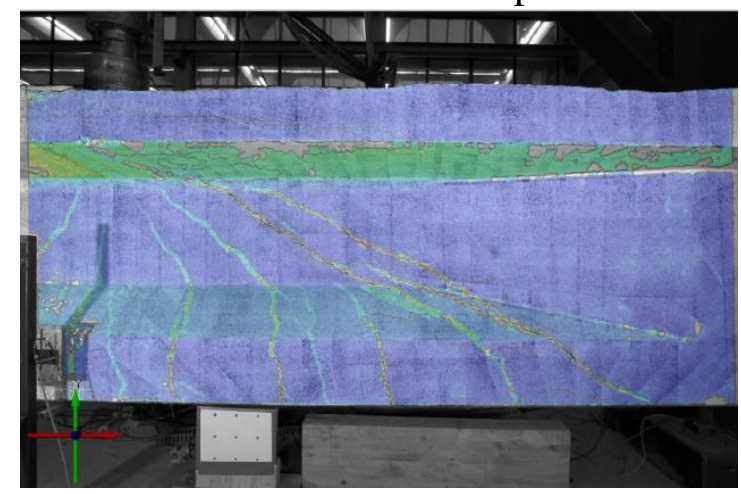

$1849 \mathrm{kN}=416 \mathrm{kip}$

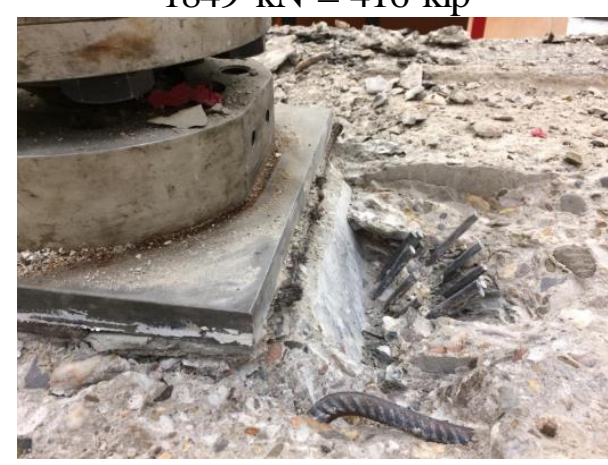

Failure, top view showing anchorage of prestressing tendon

Figure 12. Development of cracks and final failure of HPZO2. 


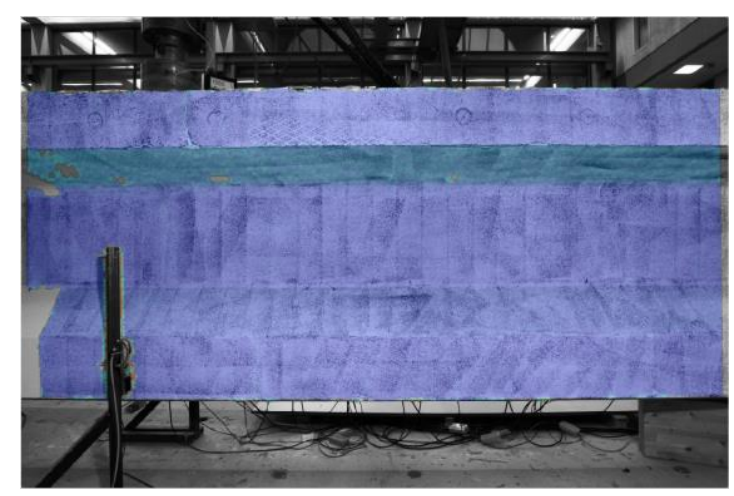

$1050 \mathrm{kN}=236 \mathrm{kip}$

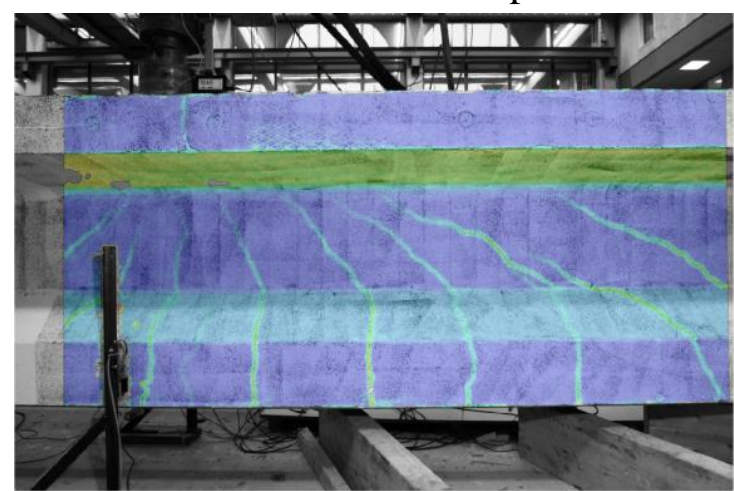

$1650 \mathrm{kN}=371 \mathrm{kip}$

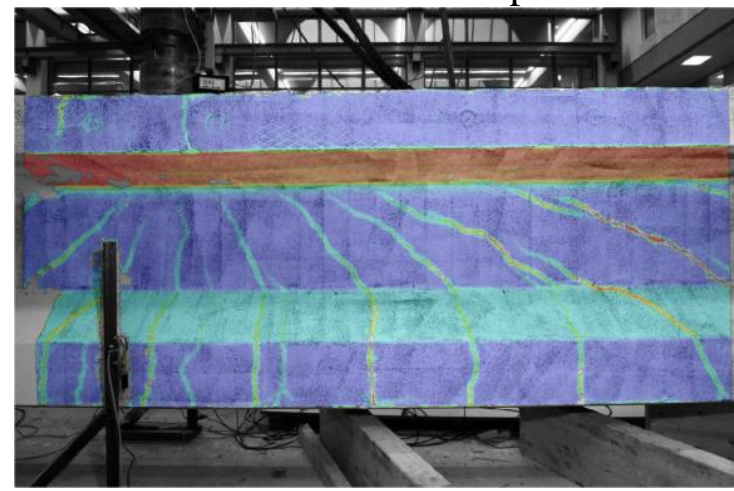

$1850 \mathrm{kN}=416 \mathrm{kip}$

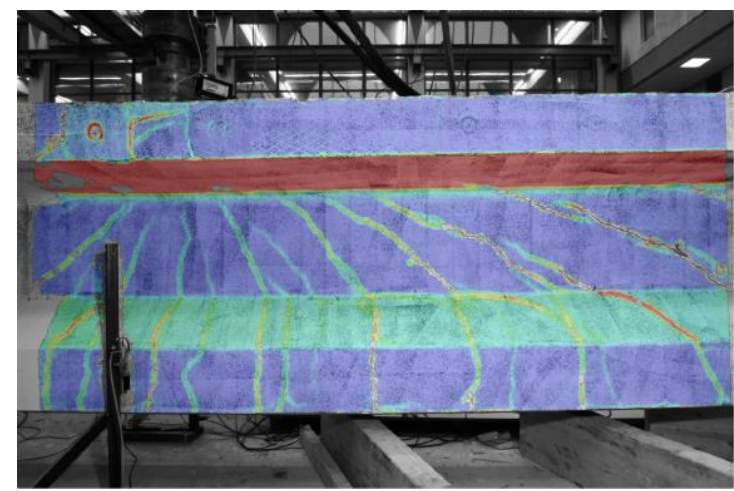

$1990 \mathrm{kN}=448 \mathrm{kip}$

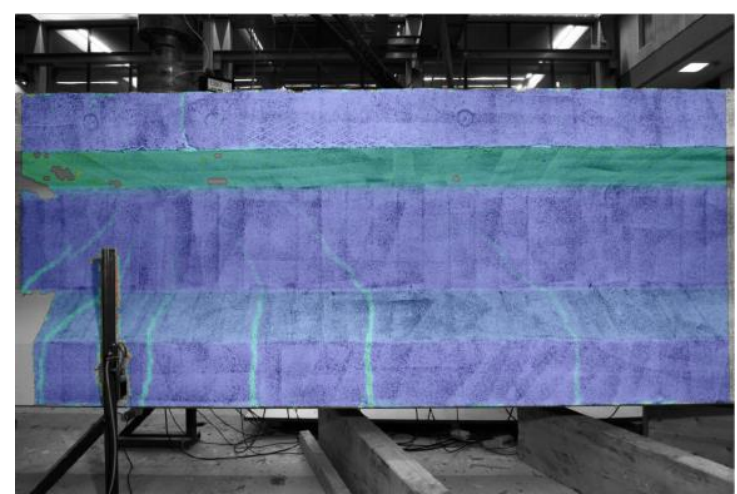

$1400 \mathrm{kN}=315 \mathrm{kip}$

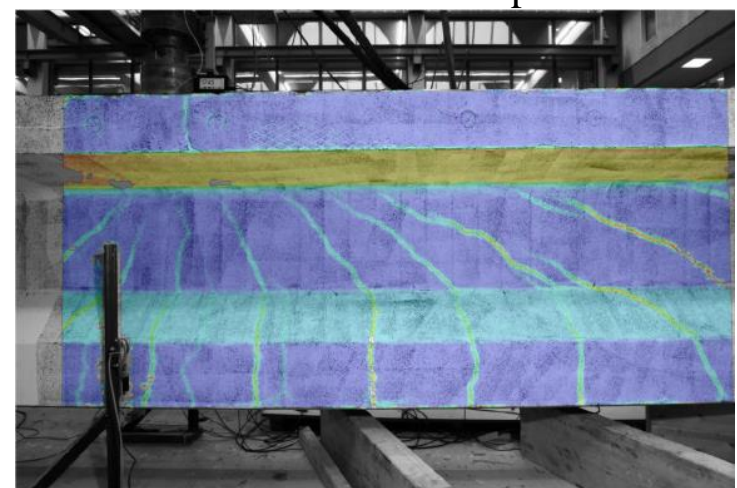

$1750 \mathrm{kN}=394 \mathrm{kip}$

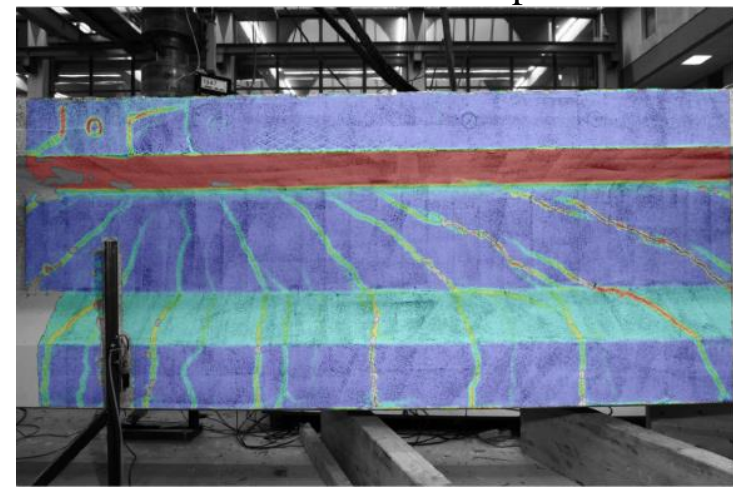

$1950 \mathrm{kN}=439 \mathrm{kip}$

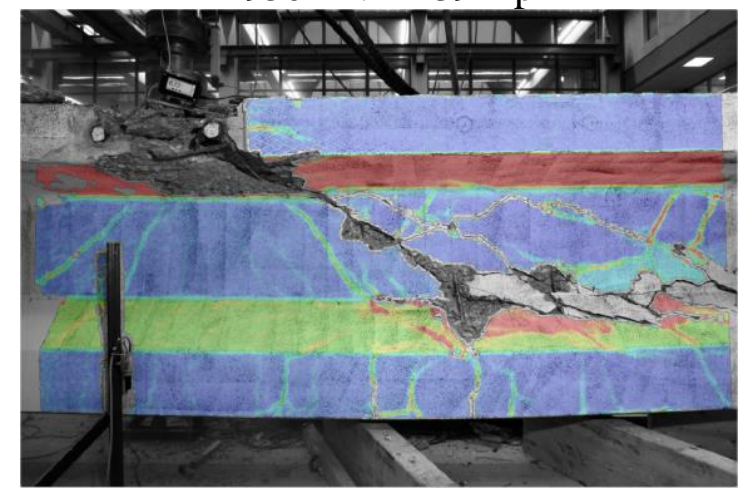

Failure by local crushing of concrete in the top flange

Figure 13. Development of cracks and final failure of HPZ03. 


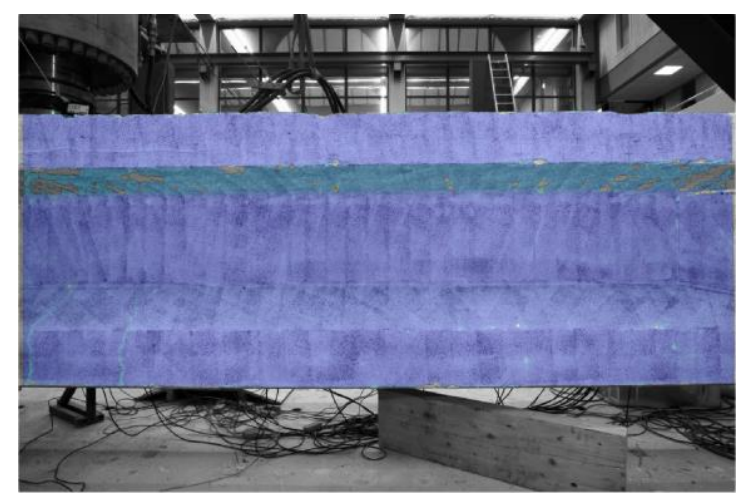

$1300 \mathrm{kN}=293 \mathrm{kip}$

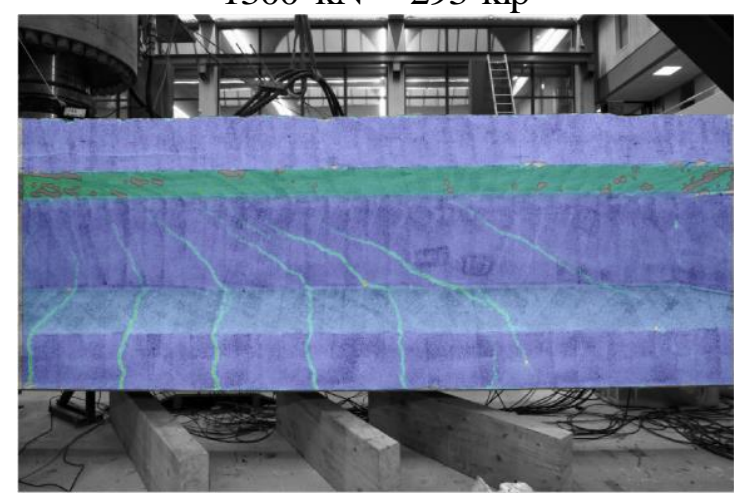

$1750 \mathrm{kN}=394 \mathrm{kip}$

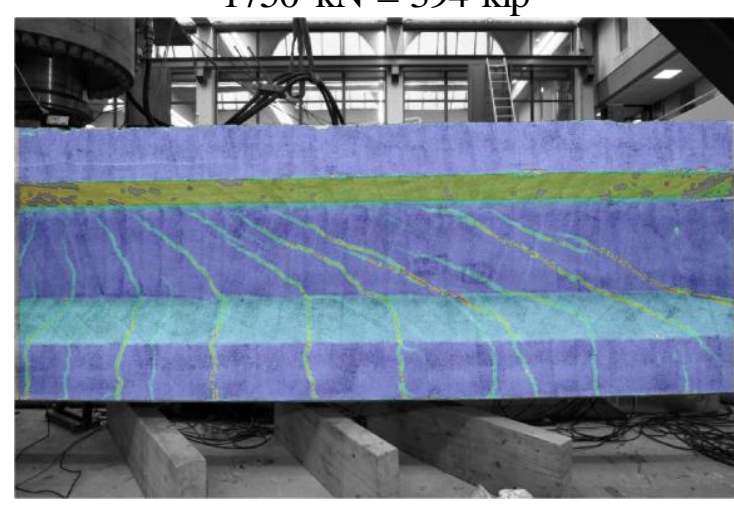

$2150 \mathrm{kN}=484 \mathrm{kip}$
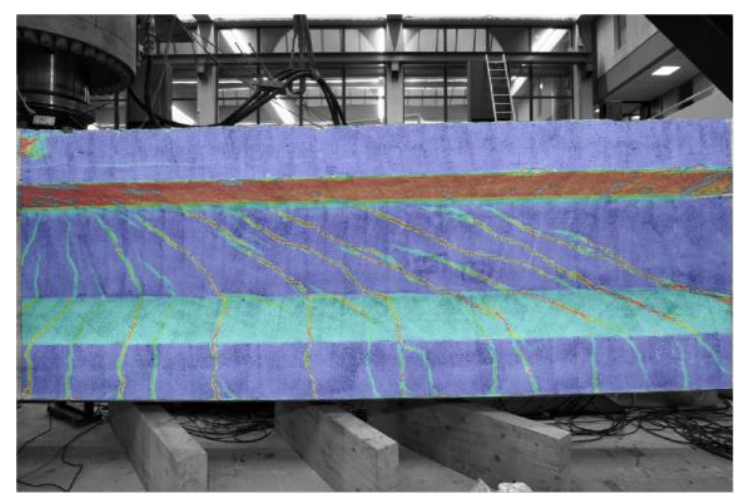

$2380 \mathrm{kN}=536 \mathrm{kip}$

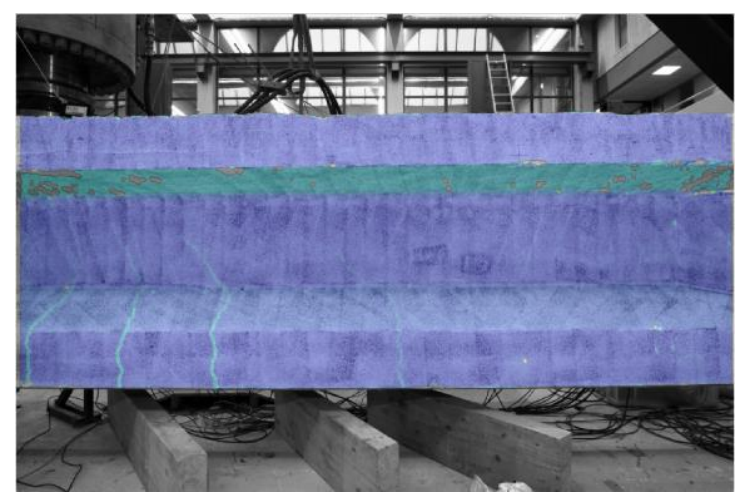

$1535 \mathrm{kN}=345 \mathrm{kip}$

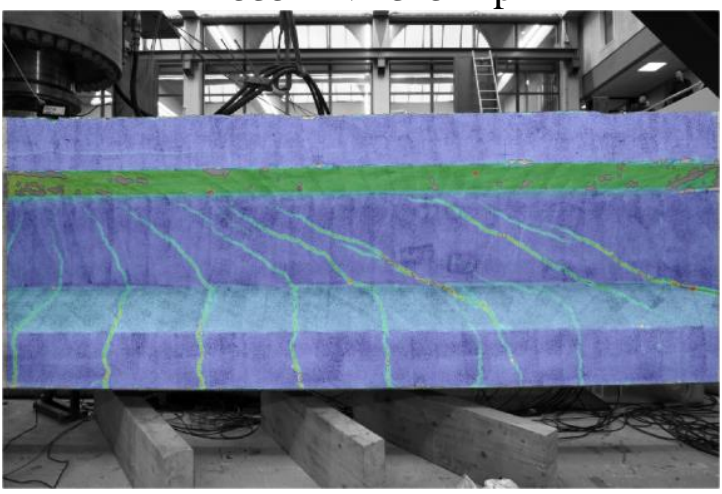

$1950 \mathrm{kN}=439 \mathrm{kip}$

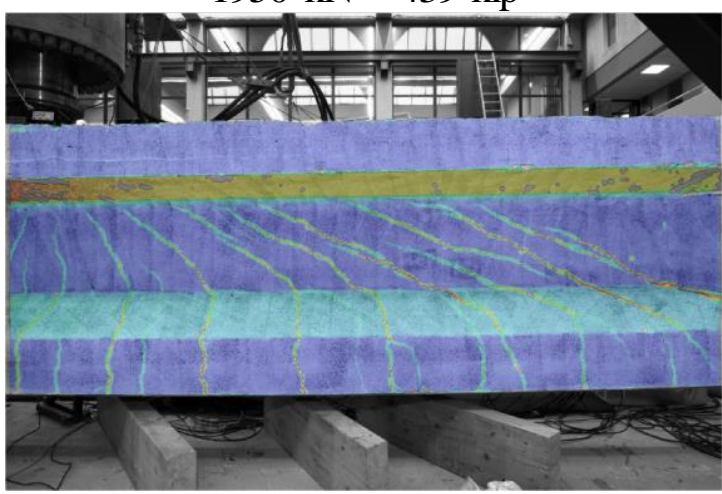

$2250 \mathrm{kN}=506 \mathrm{kip}$

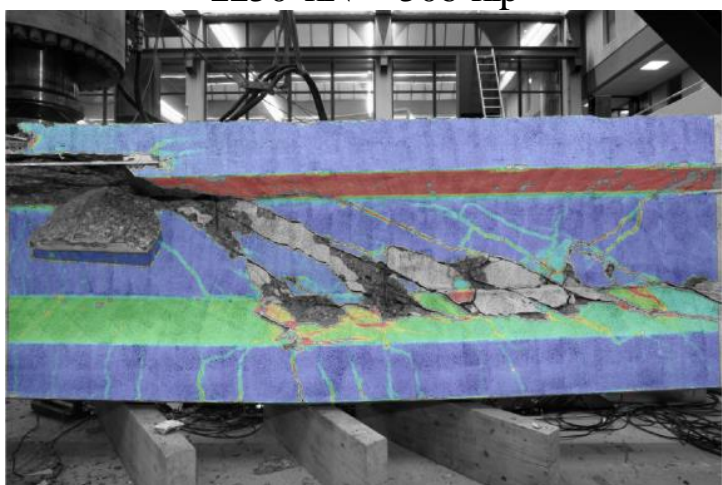

Failure by crushing of concrete in compression field in the web

Figure 14. Development of cracks and final failure of HPZ04. 


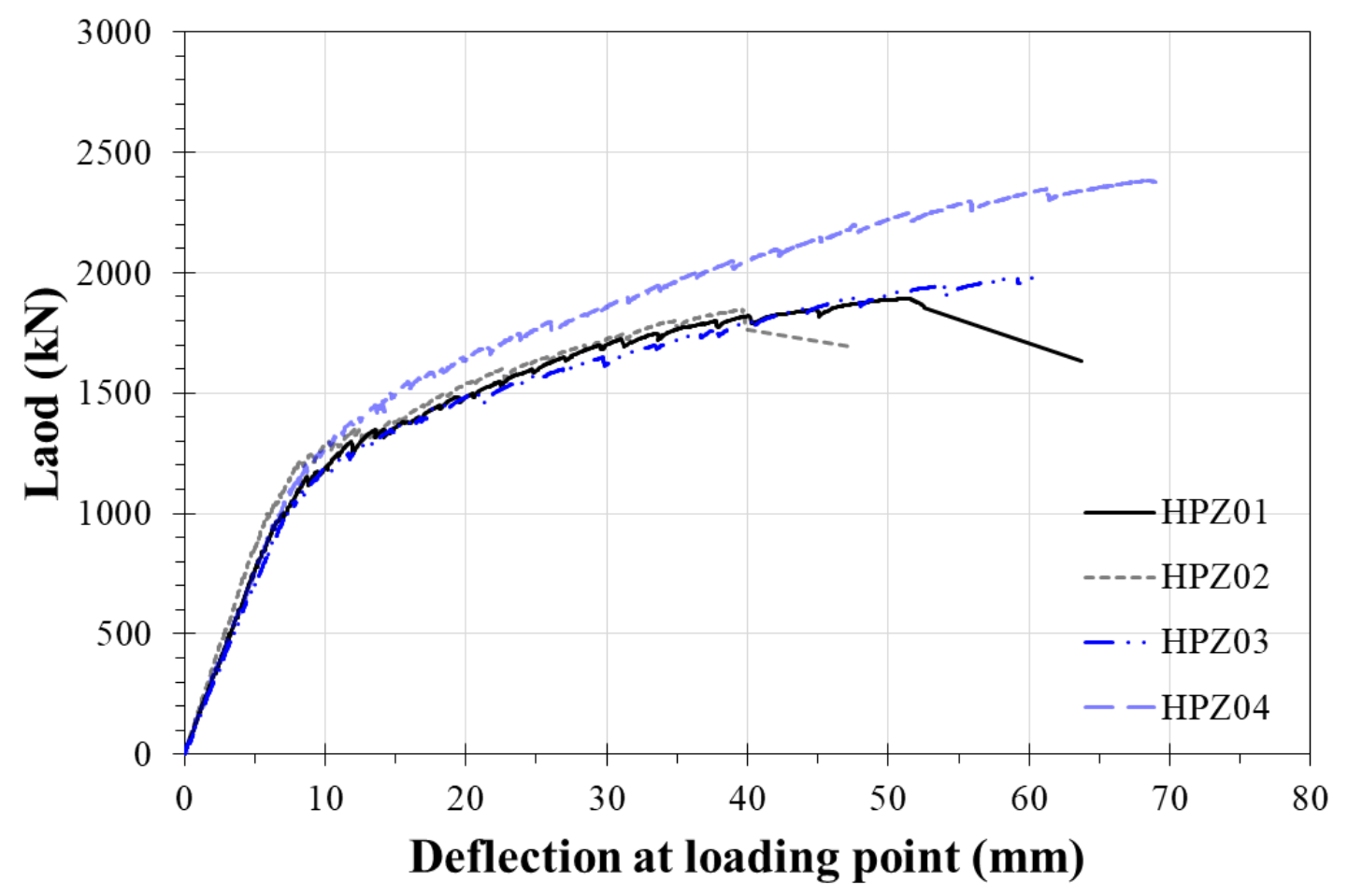

1

2 Figure 15. Load-displacement diagrams of experiments. Conve rsion: $1 \mathrm{kN}=0.225 \mathrm{kip}, 1 \mathrm{~mm}$ $3=\mathbf{0 . 0 4}$ in.

4 